\title{
Update on Interfacial Charge Transfer (IFTC) Processes on Films Inactivating Viruses/Bacteria under Visible Light: Mechanistic Considerations and Critical Issues
}

\author{
Sami Rtimi ${ }^{1,2, *(D)}$ and John Kiwi ${ }^{1, *}$ \\ 1 Ecole Polytechnique Fédérale de Lausanne, EPFL-ISIC-GPAO, 1015 Lausanne, Switzerland \\ 2 Ecole Polytechnique Fédérale de Lausanne, EPFL-STI-LTP, 1015 Lausanne, Switzerland \\ * Correspondence: rtimi.sami@gmail.com (S.R.); john.kiwi@epfl.ch or johnkiwi708@gmail.com (J.K.)
}

check for updates

Citation: Rtimi, S.; Kiwi, J. Update on Interfacial Charge Transfer (IFTC) Processes on Films Inactivating Viruses/Bacteria under Visible Light: Mechanistic Considerations and Critical Issues. Catalysts 2021, 11, 201. https://doi.org/10.3390/ catal11020201

Academic Editor: Luigi Rizzo

Received: 1 January 2021

Accepted: 29 January 2021

Published: 3 February 2021

Publisher's Note: MDPI stays neutral with regard to jurisdictional claims in published maps and institutional affiliations.

Copyright: (c) 2021 by the authors. Licensee MDPI, Basel, Switzerland. This article is an open access article distributed under the terms and conditions of the Creative Commons Attribution (CC BY) license (https:// creativecommons.org/licenses/by/ $4.0 /)$.

\begin{abstract}
This review presents an update describing binary and ternary semiconductors involving interfacial charge transfer (IFCT) in composites made up by $\mathrm{TiO}_{2}, \mathrm{CuO}, \mathrm{Ag}_{2} \mathrm{O}$ and $\mathrm{Fe}_{2} \mathrm{O}_{3}$ used in microbial disinfection (bacteria and viruses). The disinfection mechanism, kinetics and generation of reactive oxygen species (ROS) in solution under solar/visible light are discussed. The surface properties of the photocatalysts and their active catalytic sites are described in detail. Pathogenic biofilm inactivation by photocatalytic thin films is addressed since biofilms are the most dangerous agents of spreading pathogens into the environment.
\end{abstract}

Keywords: photocatalysis; bacterial inactivation; viral inactivation; disinfection mechanisms; ROS lifetimes; ROS diffusion lengths

\section{Introduction}

This update is designed primarily for students and researchers in the area of photocatalysis, describing the design, synthesis, evaluation and characterization of innovative photocatalysts allowing environmental disinfection. The advantage of supported photoactive materials is that they preclude the use of chlorinated compounds in water bodies to inactivate bacteria/viruses. Chlorination generates dangerous/carcinogenic chloro-species due to the interaction of $\mathrm{Cl}$ radical reacting with organic compounds in water under solar irradiation.

Semiconductor and inert oxides/double oxides present a mild alternative approach to disinfect water bodies. No comprehensive mechanism for the degradation of organic matter and pathogens by photocatalysis is available at the present time. There is a need for more work on stable, kinetically fast photocatalysts inactivating virus/bacteria. Recent reviews reporting environmental disinfection methods have been published recently [1-6]. This is a topic of timely interest and will motivate more research on the understanding of viral resistance to catalytic/photocatalytic treatment.

Most studies available on the photocatalytic inactivation of viruses rely on $\mathrm{TiO}_{2}$, a low-cost, inert, non-toxic semiconductor that is stable within a wide $\mathrm{pH}$ range. However, the performance of $\mathrm{TiO}_{2}$ is limited by its slow inactivation kinetics induced under solar light, resulting in long treatment times. This precludes a wide application of this approach. Doped $\mathrm{TiO}_{2}$ promoters have been reported to enhance the virus inactivation kinetics by $\mathrm{TiO}_{2}$ at a modest scale [5]. Highly porous $\mathrm{TiO}_{2}$ increasing the adsorption of dispersed virus/bacteria is a way to increase the virus disinfection kinetics. Highly porous films such as $\mathrm{TiO}_{2} / \mathrm{Ag}, \mathrm{TiO}_{2} / \mathrm{Cu}$ and $\mathrm{TiO}_{2} / \mathrm{Cu}$-apatite are not available at the present time [3-5].

Viruses constitute a group of heterogeneous organisms. They range in size from 0.01 to 0.3 microns and are much smaller compared to bacteria. They do not present independent metabolism and are fed by the host. They contain either DNA or RNA as genetic materials, but not both. The nucleic materials are surrounded by a protein and are coated to protect 
them from the action of harmful external agents. The virus external envelope contains binding sites made up of protein, lipids and polysaccharides. These functional groups are needed by the virus to attach to the host cells. The binding functional sites fuse with the receptor host cell, allowing viral replication and further infecting the host.

Virus inactivation is due to virus protein/genome damage. The complete set of reactions leading to the photocatalytic oxidation of bacteria/viruses/fungi has not been worked out at the present time [6-9]. Capsid and genetic damage occurs during the $\mathrm{TiO}_{2}$ photocatalytic inactivation of viruses. The extent of damage required for full virus inactivation is not clear. More work is required to elucidate the nature of the sites inducing viral protein damage. The viruses responsible for influenza, polio and enterococci infections have been extensively reported during recent decades, as well as adenovirus, which is widely found in contaminated food or water effluents. Enterobacteria phage (MS2) until now, is the most widely studied virus and is non-toxic to humans. Several water-borne viruses have been detected in groundwater, treated water in secondary biological municipal stations and natural water bodies. They can be transmitted from person to person, such as the case of the rotavirus, spread by the respiratory channels. Viral infection occurs when the genome/protein contacts the receptors of host cells infecting the patient. Veal, chicken, pig and lamb meat ordinarily transmit coronavirus, but in a form that cannot interact and penetrate human receptors/host cells [10].

Hybrid processes applying microfiltration and ultraviolet light (UV) light have been used for a long time, although at a reduced scale to reduce/inactivate viruses. UV treatment alone is not an effective treatment for highly turbid waters/matrices. This is mainly due to the photon screening in such non-transparent solutions. To disinfect effluents, colloids with small sizes close to the size of bacteria and/or viruses. Semiconductor and metal colloids can be prepared in very small sizes (sub-micron) as colloids presenting a high degree of transparency due to their small size. This allows large light penetration and low scattering with a balanced hydrophobic-hydrophilic behavior and suitable redox properties. This is necessary to disinfect water-borne bacteria/viruses. Coupling microfiltration with the photocatalytic process has been applied when disinfecting turbid wastewaters in a photoreactor. However, this leads to membrane fouling with concomitant costs. During virus removal and inactivation, the reaction media should present the relatively high light penetration required, allowing the disinfection process to take place.

This update presents some selected photocatalysts inactivating bacteria/viruses due to the reactive oxygen species (ROS) generated in the media. These ROS permeate into the host cell, inducing damage to the virus. Photogenerated charges damage bacteria/viruses when they migrate and translocate into the pathogen outer layers.

\section{Light-Induced Semiconductor Reactions Inducing Virus/Bacteria Inactivation}

$\mathrm{TiO}_{2}$ activated by light has been used for its stability, low cost and inertness as the model semiconductor to inactivate bacteria and viruses, despite absorbing only $4-5 \%$ of the incoming solar light. The absorbed photon by $\mathrm{TiO}_{2}$ induces an $\mathrm{e}-/ \mathrm{h}+$ pair. However, decorating or doping the $\mathrm{TiO}_{2}$ with oxides of $\mathrm{Ag}, \mathrm{Au}, \mathrm{Cu}, \mathrm{Pt}, \mathrm{Fe}, \mathrm{Ni}, \mathrm{Pd}$ and $\mathrm{Rh}$ enhances the visible light absorption capability of $\mathrm{TiO}_{2}$. Interfacial charge transfer (IFCT) processes occur between $\mathrm{TiO}_{2}$ and the metal oxide, absorbing light in the visible range. In the case of $\mathrm{TiO}_{2}$, IFCT processes involve electron transition from anatase to rutile in the $\mathrm{TiO}_{2}$ heterostructure. This is possible due to the higher conduction band position of anatase (cb1) with respect to the rutile conduction band position ( $\mathrm{cb} 2)$.

The incident light induces electron pair separation in the semiconductor followed by the generation of reactive oxygen species (ROS) in solution. These species are short-lived, present high redox potentials and were seen to effectively inactivate Escherichia coli (E. coli). ROS cause oxidative stress in the bacteria, and the oxygen singlet ${ }^{1} \mathrm{O}_{2}$ generated in solution leads to peroxidation of the bacterial envelope [11,12]. The peroxidation step arises from the $\mathrm{H}$-abstraction from an unsaturated fatty acid in the E. coli lipopolysaccharide (LPS) bilayer and leads to lipid radicals, as shown in Figure 1a. Within longer times, the oxidative 
radical $R$ leads to the formation of further ROS in solution. This is shown schematically in Figure $1 b$.

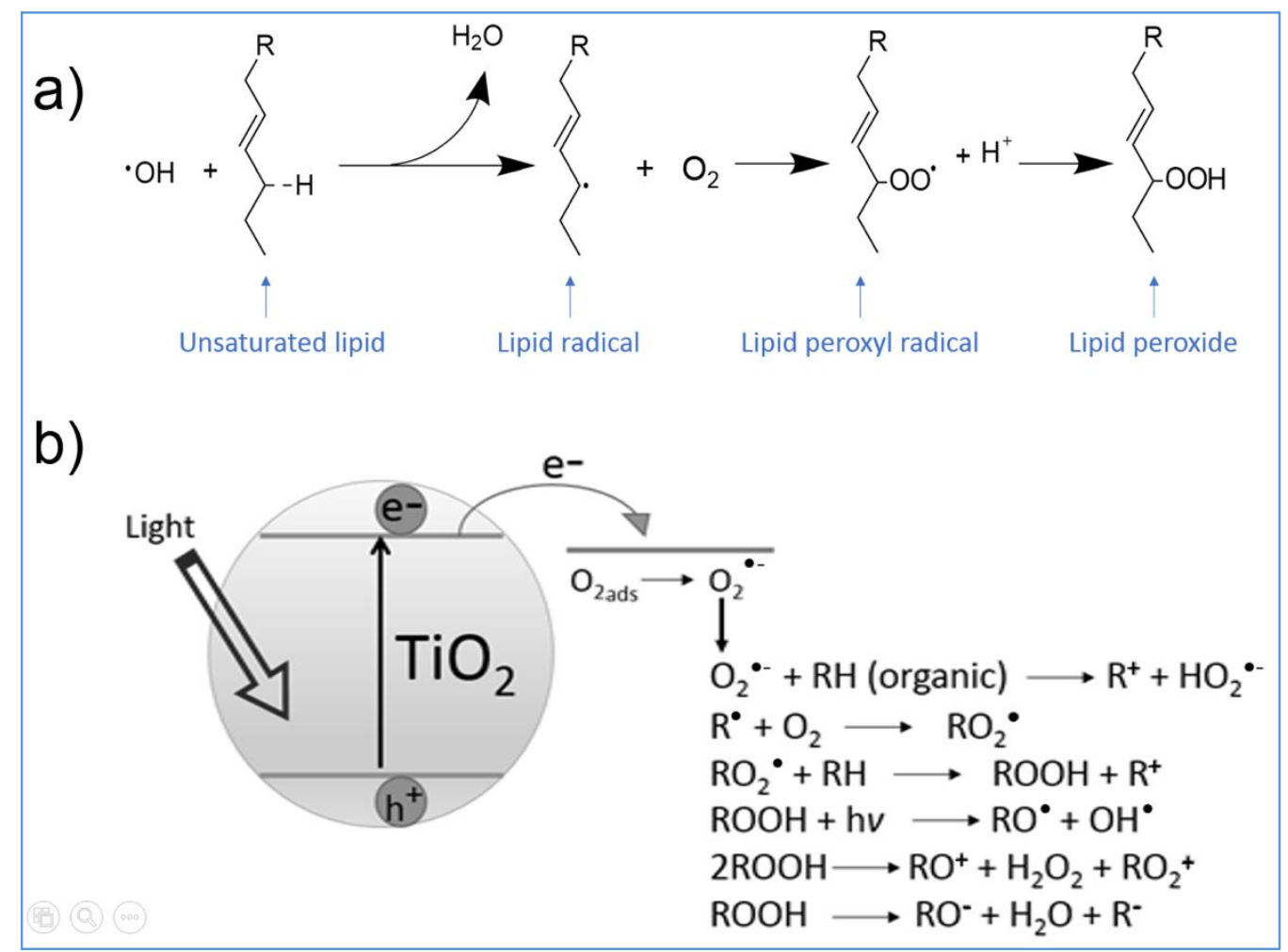

Figure 1. (a) H-abstraction from an unsaturated fatty acid in the lipopolysaccharide (LPS) topmost bilayer of E. coli, leading to cell envelope peroxidation. This is the precursor step for the generation of lipid radicals, initiating the mechanism leading to bacteria/virus degradation. (b) Schematic steps suggested for $\mathrm{TiO}_{2}$-mediated generation of reactive oxygen species (ROS) in solution under band gap irradiation, leading to bacteria/virus degradation.

The E. coli envelope consists of lipopolysaccharides (LPS) and phosphatidyl-ethanolamine (PE) bilayers, and these bilayers photodegrade during $\mathrm{TiO}_{2}$-mediated photocatalysis. Within longer times, the most resistant layer of the envelope, the peptidoglycan (PGN), gets damaged, leading to several peroxidation products. Depending on the type of bacteria used, the degradation products consist of aldehydes, ketones, carboxylic acids and residual organic oxidized intermediates. Full mineralization of the bacteria leads to $\mathrm{CO}_{2}$, water and inorganic anions such as $\mathrm{NO}_{3}{ }^{-} / \mathrm{SO}_{4}{ }^{2}[13,14]$.

Light irradiation to inactivate viruses has revealed that adenoviruses are highly resistant to irradiation by UV [15]. The United States Environmental Protection Agency (USEPA) has increased the UV fluence requirements for $4-\log _{10}$ removal of viruses from 40 to $186 \mathrm{~mJ} / \mathrm{cm}^{2}$. This latter dose was shown to be necessary to completely deactivate the virus. This implies a higher amount of energy/costs necessary to inactivate this kind of pathogens. More efficient photocatalysts are required at the present time. Adenovirus is resistant to conventional treatment since its genome is mainly DNA and not RNA. This enables the virus to utilize the DNA repair enzymes present in the host cells to repair its genome damage, increasing its resistance to disinfection. Metals can undergo specific redox covalent reactions with the topmost functional groups of the virus or cells' outer layers. This involves redox reactions between the metal/ions and generates organometallic toxic species, leading to cell inactivation in the dark or under light [16-19].

Singlet oxygen has been reported to inactivate MS2 by the oxidation of amino acid residues $[3-5,20]$. Binary $\mathrm{TiO}_{2}-\mathrm{SiO}_{2}$-mediated photocatalysts have shown improved virus inactivation ability when compared to bare $\mathrm{TiO}_{2}$ due to the finer dispersion of the $\mathrm{TiO}_{2}$ nanoparticles (NPs) reached on the $\mathrm{SiO}_{2}$. Hydrogen peroxide was found to be an effective 
additive in the dark for the reduction of viruses on stainless steel and, when used in conjunction with UV, led to a faster inactivation compared to $\mathrm{H}_{2} \mathrm{O}_{2}$ applied alone. For this reason, combined hydrogen peroxide-UV treatments to reduce viruses from many foods have been used during recent years.

\section{Virus Inactivation by $\mathrm{TiO}_{2}$ under Light}

\subsection{Enterococcal Viruses}

The enteric group of viruses are not able to replicate in the environment outside of their hosts. Visible light-irradiated $\mathrm{TiO}_{2}$ was seen to produce $\mathrm{ROS}$ in solution, leading to the inactivation of rotavirus and astrovirus. Human noroviruses are the most common cause of viral gastroenteritis. Fluorinated $\mathrm{TiO}_{2}$ films have been shown to more effectively inactivate human norovirus under visible light compared to $\mathrm{TiO}_{2}$ by itself. One hour of irradiation with fluorescent light at $10 \mathrm{~mW} / \mathrm{cm}^{2}$ reduced norovirus approximately $3-4 \log _{10}$. When no light was applied, no detectable reduction was observed. The norovirus destruction was due to ROS and was accelerated by the presence of F-radicals leaching out of the catalyst surface [6]. Different viruses have been found in treated sewage leading to infections, despite the information reported by municipal treating stations that they are complying with the legislation on the standard microbiological water treatment. This revealed insufficient municipal treatment of wastewater viruses and enteric bacteria [15]. A more stringent evaluation of biologically treated water is needed nowadays to ensure the quality of drinking water and ensure that it is free of viruses.

\subsection{Poliovirus}

Poliovirus was effectively inactivated by titanium dioxide photocatalysis. The rates were more rapid than for the inactivation of coliform bacteria. However, the photocatalytic disinfection of effluents using titanium dioxide under sunlight is severely limited due to the relatively slow inactivation kinetics. Polio virus 1 was $99.9 \%$ killed in secondary waste effluent after $30 \mathrm{~min}$ of irradiation with 40-W black light in phosphate buffer Dulbecco's Phosphate Buffered Saline (DPBs) $\mathrm{TiO}_{2}$ P25 dispersions [2].

\subsection{Influenza}

The influenza virus has been shown to be inactivated by $\mathrm{TiO}_{2}$ photocatalysis. First, the protein present was deactivated, and subsequently, RNA was attacked. The data suggest that the photocatalytic activity destroys the viral binding proteins. The degradation of the proteins was due to ROS, mainly involving $\bullet \mathrm{OH}$ and $\mathrm{O}_{2} \bullet$ - produced by the $\mathrm{TiO}_{2}$ photocatalysis. The virus inactivation depends on the UV-A intensity and irradiation time. Titanium dioxide photocatalysis under UV light can inactivate $4-\log _{10}$ influenza virus within a short time at extremely low doses of UV-A $\left(0.01 \mathrm{~mW} / \mathrm{cm}^{2}\right)[21,22]$.

\subsection{Adenovirus}

Adenoviruses are found widely in contaminated food or sewage water. UV-C treatment has been used at a laboratory scale and induced a higher reduction of virus than UV-A and UV-B. Adenoviruses' inactivation in the water supply chain is, in some instances, carried out using monochloramine with the generation of undesirable DBPs. Adenoviruses' contamination of water systems allow adenovirus to cycle through the environment. It is also transmitted from person to person, as in the case of the rotavirus. This virus spreads by respiratory/oral pathways by contact with the host cells of the receptor. After contact with the host cell, adenovirus produces the proteins required for further genetic replication. Adenoviruses proceed when significant damage takes place on their capsid structure. In contrast to MS2, adenovirus proteins were inactivated within acceptable times during the $\mathrm{TiO}_{2}$-mediated photocatalytic process. The adenovirus undergoes damage to its genomes by UV254 light. However, even when damaged, is still capable of infecting cells. Viruses use the host cell enzymes to repair their damaged DNA and then replicate, allowing for further infection of a variety of host cells. 


\section{Parameters Controlling the Photocatalytic Virus Inactivation}

The sections below briefly describe the solution parameters controlling pathogen inactivation in solution. Most of the available scientific literature reports studies on $\mathrm{TiO}_{2}$ deactivation of bacteria, but not viruses. The photocatalytic inactivation of viruses follows the methodology and photochemical set-ups used to inactivate bacteria. The experimental use is adjusted for the features of viruses.

\subsection{Effect of the Catalyst Concentration}

A higher catalyst concentration accelerates the virus inactivation kinetics, but this process is limited by the optical density of the solution. The limit is set by the light penetration into the reactor volume [1-5]. Increasing the concentration of $\mathrm{TiO}_{2}$ or $\mathrm{TiO}_{2} / \mathrm{Ag}$ enhanced ROS production and led to an enhanced virus inactivation. The NP concentration mediating virus inactivation should be much higher than the photons $/ \mathrm{sec} / \mathrm{cm}^{2}$ reaching the photochemical reactor. Saturation with the incoming photons of the photocatalyst NPs by the solution is another limiting parameter to consider during virus inactivation processes. Silver NPs were reported to enhance the $\mathrm{TiO}_{2}$ photocatalytic inactivation kinetics of viruses. Silver also has a high affinity for sulfur (cysteine) and carboxyl groups present in the topmost virus bilayer. The latter functional groups bind silver [23,24].

\subsection{Effect of Light Intensity}

A higher light intensity leads to higher bacterial photocatalytic inactivation kinetics, but in certain limits. It increased linearly with the applied light dose when lower light intensities were used. However, the reaction rate only increased with the square root of the intensity at intermediate intensities. At higher light intensities, the rates increase only marginally or not at all. It was observed that the inactivation rates became constant after a certain threshold [25]. The reason for this is that higher light intensities lead to a faster recombination of the photogenerated charges (electrons and holes) in semiconductors such as $\mathrm{TiO}_{2}$ [1-5]. The range and dose of the applied light have a controlling effect on the bacterial inactivation kinetics. Figure 2 shows the range of the light applied in photocatalytic processes.

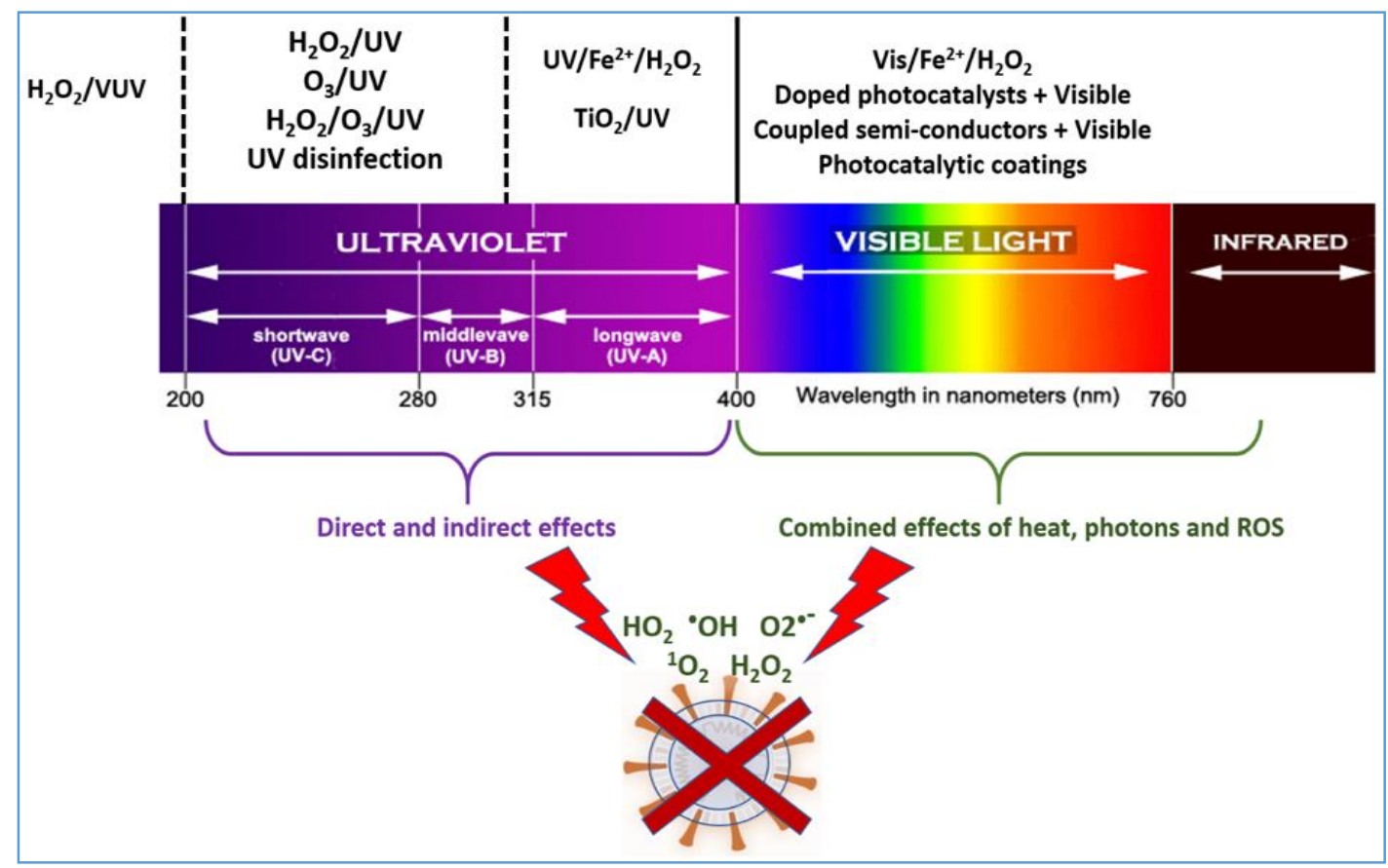

Figure 2. Range of the applied light effective in viral/bacterial inactivation in semiconductors and semiconductors doped by metals or oxides. Decorated, doped semiconductors present interfacial charge transfer (IFCT) processes under solar/visible light. 
$\mathrm{TiO}_{2}$ coatings and metal /oxide composites have been reported to inactivate a wide variety of microorganisms in small- or large-size reactors [1-5]. The variation of the light dose within a day had important effects on the pathogen inactivation kinetics, as the wavelength of the incident light changes during daily solar irradiation as a function of the time. UV-A and UV-B have been widely reported to inhibit cellular activity in the presence of $\mathrm{TiO}_{2}$ or doped $\mathrm{TiO}_{2}$, and the observed inactivation kinetics is a function of (a) the type of virus and/or bacteria colonies to be inactivated and (b) the concentration of pathogens. A bovine rotavirus was inactivated within $3 \mathrm{~h}$ and a $3 \log _{10}$ concentration reduction was observed under solar light irradiation. Poliovirus was inactivated by applying a solar dose of $85 \mathrm{~mW} / \mathrm{cm}^{2}$ at $25^{\circ} \mathrm{C}<6 \mathrm{~h}$. E. coli was disinfected under identical conditions within shorter times.

\subsection{Contact between the Virus and the $\mathrm{TiO}_{2}$ Surface}

A higher surface area of a $\mathrm{TiO}_{2} \mathrm{NP}$ photocatalyst has been reported to lead to faster bacterial inactivation kinetics compared to samples prepared at higher temperatures and presenting lower specific surface areas (SSAs) [26]. A closer contact of the $\mathrm{TiO}_{2} \mathrm{NPs}$ with bacteria/viruses has been reported to accelerate the pathogen inactivation kinetics [27]. The binding of the $\mathrm{TiO}_{2}$ NPs to bacterial cells involves electrostatic, van der Waals forces, $\mathrm{pH}$, agglomeration of the catalyst and the NPs' surface potential.

\section{Photocatalytic Mechanism Leading to Virus/Bacterial Inactivation}

$\mathrm{TiO}_{2}$ photocatalysis processes damage protein, leading to viral capsids and releasing DNA, involving protein and genome degradation $[5,6]$. The inactivation sequence of a virus involves the following steps: (a) modification of the protein sequence cross-linking, (b) disruption of the protein conformation, (c) disruption of the protein aggregated size and (d) disruption of the transfer of the viral genome to the host cells. The surface area of the $\mathrm{TiO}_{2}$ and its size, crystallographic structure and porosity control the amount of ROS produced in the solution leading to pathogen inactivation. The salts, cations and anions found in the solution interfere with the contact between the catalyst and the pathogen, hindering the bacterial/virus inactivation. Impurities and additives can also interfere and partially inhibit the adsorption of the pathogen onto the $\mathrm{TiO}_{2} \mathrm{NPs}$.

Organic compound sensitizers are found in natural water bodies. Solar sensitizers transmit their energy by contact/diffusion to waterborne viruses [3-8]. These organic sensitizers adsorb solar irradiation and interact with the $\mathrm{O}_{2}$ dissolved at normal temperature and pressure in water $(8 \mathrm{mg} / \mathrm{L})$. Sensitizers are activated by visible light when reacting with the dissolved $\mathrm{O}_{2}$ present in the ground state as a triplet state. Triplet-triplet energy transfer occurs between $\mathrm{S}^{*}$ and ${ }^{3} \mathrm{O}_{2}$ or by a second deactivation channel electron transfer from the $S^{*}$ to oxygen. Alternatively, the electron can transfer from the $S^{*}$ to the superoxide radical anion $\mathrm{O}_{2}{ }^{-}$in the solution at biological $\mathrm{pH}$ values of 5.7-8.0. The sensitizer (S) can either transfer the energy, leading to excited $\mathrm{O}_{2}{ }^{*}$ by reaction (1), or react subsequently by charge transfer with dissolved $\mathrm{O}_{2}$, as shown in reaction (2):

$$
\begin{gathered}
\mathrm{S}+\text { solar light } \rightarrow \mathrm{S}^{*}+\mathrm{O}_{2} \rightarrow \mathrm{S}+\mathrm{O}_{2}^{*} \\
\mathrm{~S}^{*}+\mathrm{O}_{2} \rightarrow \mathrm{S}^{+}+\mathrm{O}_{2}^{\bullet-}
\end{gathered}
$$

The excited $\mathrm{O}^{*}$ species and the radicals $\mathrm{O}_{2}{ }^{\bullet-}$ in Equations (1) and (2) lead to the oxidation of bacteria/viruses. The $\mathrm{O}_{2}{ }^{\bullet-}$ radical exists in solution at the biological $\mathrm{pH}(6-8)$, since the $\mathrm{pK}_{\mathrm{a}}$ of the equilibrium $\mathrm{HO}_{2}{ }^{-} \rightarrow \mathrm{H}^{+}+\mathrm{O}_{2}{ }^{\bullet-}$ is 4.8. ROS radicals such as the ${ }^{\bullet} \mathrm{OH}$ radicals $\mathrm{OH} / \mathrm{OH}^{-}$presenting a thermodynamic potential Normal Hydrogen Electrode potential $\left(\mathrm{NHE}-1.90 \mathrm{eV}\right.$ ) and $\mathrm{HO}_{2} / \mathrm{O}_{2}{ }^{-}(\mathrm{NHE}-0.65 \mathrm{eV})$ present a short diffusion length in solution. The ${ }^{\bullet} \mathrm{OH}$ and $\mathrm{HO}_{2}{ }^{\bullet-}$ interact with pathogens, pollutants, salts and dissolved organic matter $(\mathrm{DOM})$ in solution within the range of their respective diffusion spheres. The diffusion of both radicals has been estimated from the simplified Smoluchowski equation. Furthermore, one has to consider the time span in which the sensitizer (S) reacts with the 
dissolved $\mathrm{O}_{2}$ to produce $\mathrm{ROS}$ radicals in the solution. The next paragraph describes the estimation of ROS lifetimes and the diffusion length of these ROS radicals.

The concentration of $\mathrm{O}_{2}$ is $8 \mathrm{mg} / \mathrm{L}$ or $0.5 \times 10^{-3} \mathrm{M}$ in water and is used to estimate the lifetime of the reaction pair made up by the sensitizer $(\mathrm{S})$ and $\mathrm{O}_{2}$. The reaction time $(\tau)$ can be estimated from the relation $1 / \tau=0.5 \cdot 10^{-3} \mathrm{M} \times 6 \cdot 10^{9} \mathrm{M}^{-1} \cdot \mathrm{s}^{-1}=3 \cdot 10^{6} \mathrm{~s}^{-1}$ or $0.33 \mathrm{us}$. The diffusion distance $(\mathrm{x})$ of the ${ }^{\bullet} \mathrm{OH}$ radical away from the catalyst surface is estimated by way of the simplified Smoluchowski relation. The reaction rate between ${ }^{\bullet} \mathrm{OH}$ and the organic compound (RH) in aqueous solution is $k_{\mathrm{OH}}=10^{-9} \mathrm{M}^{-1} \cdot \mathrm{s}^{-1}$, and if the concentration of $(\mathrm{RH})$ is $10^{-2} \mathrm{M}$, the lifetime of the reaction pair is noted in Equation (3) below:

$$
\frac{1}{\tau}=k_{\bullet} \mathrm{OH}[R H]=10^{7} \mathrm{~s}^{-1} \text { and } \tau=0.1 \text { us }
$$

The motility/diffusion of the ${ }^{\bullet} \mathrm{OH}$ radical can also be estimated by the Smoluchowski relation $x^{2}=D \tau$ inserting $\mathrm{D}=5 \times 10^{-6} \mathrm{~cm}^{2} \cdot \mathrm{s}^{-1}$, the average value for the diffusion of small molecules in aqueous solution. The diffusion length for the ${ }^{\bullet} \mathrm{OH}$ radical in solution is $\mathrm{x}=$ $0.7 \times 10^{6} \mathrm{~cm}$ or $70 \AA$. The diffusion length $(\mathrm{x})$ of the $\mathrm{HO}_{2}{ }^{\bullet}$ radical can also be estimated by the simplified Smoluchowski diffusion equation. The reaction rate constants for the $\mathrm{HO}_{2} \bullet$ radical have been reported by fast kinetic spectroscopy in the range $\mathrm{k}=10^{5}-10^{7} \mathrm{M}^{-1} \cdot \mathrm{s}^{-1}$.

$$
\text { Then, } \frac{1}{\tau}=10^{4} \mathrm{~s}^{-1}
$$

and the lifetime found is of $\tau$ is $0.1 \mathrm{~ms}$. The diffusion of the $\mathrm{HO}_{2} \bullet$ in solution is estimated as $\mathrm{x}=2000 \AA$, taking the average reaction rate $\mathrm{k}_{\text {for }} \mathrm{HO}_{2} \bullet$ radicals as $\sim 10^{6} \mathrm{M}^{-1} \cdot \mathrm{s}^{-1}$.

ROS leading to virus inactivation considers (a) that mass transfer does not play a role in the virus ROS transfer process and (b) that no activation energy is required for ROS radical reactions with viruses. The quenching of singlet oxygen ${ }^{1} \mathrm{O}_{2}$ by $\mathrm{NaN}_{3}$ has been used frequently to identify ${ }^{1} \mathrm{O}_{2}$ and quantify its presence in solution. However, this approach presents a drawback: azides also react with the ${ }^{\bullet} \mathrm{OH}$ radical at a rate close to its reaction with ${ }^{1} \mathrm{O}_{2}$. Singlet oxygen ${ }^{1} \mathrm{O}_{2}$ has been reported with a lifetime of $3.6 \mathrm{~ms}$ and a diffusion motility of $\sim 75 \mathrm{~nm}$ in solution. This length is above the observed diffusion length for the $\bullet \mathrm{OH}$ radical motility in solution of $\sim 70 \AA$. The reason for this is that the singlet oxygen is a species in the gas phase and the $\mathrm{OH}$ radical is a species in solution. ${ }^{1} \mathrm{O}_{2}$-mediated processes lead to E. coli, adenovirus and MS2 and many other pathogens' inactivation [27,28]. Singlet oxygen has also been reported to hinder MS2 genome replication and oxidize virus protein.

The $\mathrm{OH}$ radical presents an oxidation potential ${ }^{\bullet} \mathrm{OH} / \mathrm{OH}^{-} 1.9 \mathrm{eV}$ NHE [5] and is high enough to lead to inactivation of the MS2 virus and oxidize capsid proteins. However, the quantification of the intermediate ROS leading to virus inactivation has not been fully reported until now.

Bacteria and viruses can sorb on dissolved organic matter (DOM) in solutions and water bodies. This increases the probability of encounters between ROS and the DOM particles adsorbed on the surface of bacteria/viruses. DOM-virus interactions have been reported for capsid proteins due to cation bridges, electrostatic, steric, hydrophobic and carboxylate effects.

\section{IFCT $\mathrm{Ag} / \mathrm{TiO}_{2}-$ Mediated Bacterial/Virus Inactivation}

In recent years, photocatalytic heterostructures have been reported, presenting increased absorption in the visible region. This is attained by decorating/doping $\mathrm{TiO}_{2}$ and $\mathrm{ZnO}$ semiconductors with metals, oxides and double oxides absorbing in the visible region. In the latter case, IFCT processes take place and (a) increase the separation of charge carriers in the semiconductor, (b) suppress the recombination rate of photoinduced electron-hole pairs, thus improving photocatalytic efficiency, (c) induce synergistic effects induced by the components in the heterostructure and, (d) in some cases, increase photostability of the composite [29]. 
Metallic oxides with oxygen vacancies such as W-oxides are of growing interest in the field of visible light-driven photocatalysis as they exhibit a wide absorption tail in the Near Infrared Region (NIR). This is due to oxygen defects. The combination of $\mathrm{TiO}_{2}$ with poly-oxometalla (tes leads to a hybrid photocatalyst absorbing in the UV and visible region [30].

$\mathrm{Ag}$ is the oldest antimicrobial agent and has been known for 2000 years. Its antibacterial features have been reported in a series of reviews [5-7]. Silver is known to be antimicrobial, biocompatible and non-toxic to humans at levels $<0.1 \mathrm{mg} / \mathrm{L}$. The virus inactivation kinetics mediated by $\mathrm{TiO}_{2} / \mathrm{Ag}$ is enhanced by the photogenerated charges in the $\mathrm{TiO}_{2}$ surface increasing the Ag disinfection activity due to the presence of ROS radicals in solution. Higher Ag contents decrease the amount of light reaching the $\mathrm{TiO}_{2}$ surface and reduce the generation of electrons, precluding the ability to inactivate pathogens. The interfacial charge transfer (IFCT) induced by $\mathrm{TiO}_{2}$ nanoparticles $\left(\mathrm{TiO}_{2} / \mathrm{Ag} \mathrm{NPs}\right)$ in solution under visible light is shown below in Figure 3.

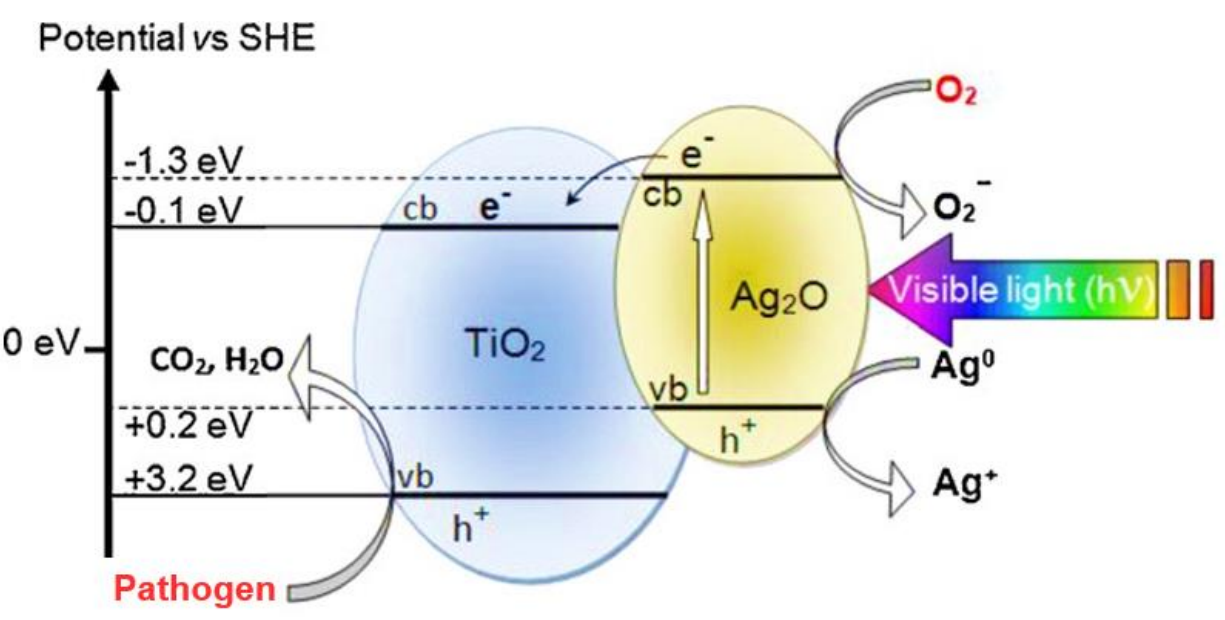

Figure 3. Interfacial charge transfer (IFCT) in $\mathrm{TiO}_{2} / \mathrm{Ag}$ NPS in solution under visible light.

Ag surface plasmon resonance (SPR) sites build up in Ag clusters of $\mathrm{TiO}_{2} / \mathrm{Ag}$ surfaces and this favors light absorption. $\mathrm{TiO}_{2} / \mathrm{Ag}$ increases the generation of $\mathrm{ROS}$ radicals such as $\mathrm{HO}_{2}{ }^{\bullet-}$ and ${ }^{\bullet} \mathrm{OH}$ radicals and ${ }^{1} \mathrm{O}_{2}$, leading to the degradation of viruses such as adenovirus, rotavirus and astrovirus. $\mathrm{TiO}_{2} / \mathrm{Ag}$ has been reported to increase the sorption/adsorption of pathogens compared to bare $\mathrm{TiO}_{2}$ in the dark and under light. The $\mathrm{TiO}_{2} / \mathrm{Ag}$ photocatalytic action is commonly rationalized in terms of an enhanced charge separation at the surface of the $\mathrm{TiO}_{2}$ by the Ag dopant hindering the e-/h+ charge recombination.

Variation of the of the rutile/anatase ratio in the catalyst make-up led to a variation of the kinetics of MS2 virus inactivation. Ag photocatalysis leads to the formation of ROS species $[23,24]$. Ag reacts almost instantaneously with air $\left(\mathrm{O}_{2}\right)$ and atmospheric water vapor, leading to AgOH. Only 2-3 atomic layers of $\mathrm{AgOH}(0.4-0.6 \mathrm{~nm}$ thick) are found on NPs' surfaces [31]. AgOH decomposes spontaneously to $\mathrm{Ag}_{2} \mathrm{O}$.

$$
2 \mathrm{AgOH} \rightarrow \mathrm{Ag}_{2} \mathrm{O}+\mathrm{H}_{2} \mathrm{O} \quad\left(\mathrm{pk}_{\mathrm{a}}=2.87\right)
$$

$\mathrm{Ag}_{2} \mathrm{O}$ is thermodynamically stable in the $\mathrm{pH}$ 6-8 range, the physiological $\mathrm{pH}$ range of bacteria. Visible light irradiation activates $\mathrm{Ag}_{2} \mathrm{O}$, generating electrons and holes:

$$
\mathrm{Ag}_{2} \mathrm{O}+\text { light } \rightarrow \mathrm{Ag}_{2} \mathrm{Ocbe}^{-}+\mathrm{Ag}_{2} \mathrm{Ovbh}^{+}
$$

and the photogenerated build-up of $\mathrm{O}_{2}^{\bullet-}, \bullet \mathrm{OH}$ and $\mathrm{HO}_{2} \bullet$ radicals as outlined next:

$$
\begin{gathered}
\text { e- }+\mathrm{O}_{2} \rightarrow \mathrm{O}_{2}^{\bullet-} \\
\mathrm{e}-+\mathrm{H}_{2} \mathrm{O}+1 / 2 \mathrm{O}_{2} \rightarrow{ }^{\bullet} \mathrm{OH}+\mathrm{OH}^{-}
\end{gathered}
$$




$$
\begin{gathered}
\mathrm{h}^{+}+\mathrm{H}_{2} \mathrm{O} \rightarrow{ }^{\bullet} \mathrm{OH}+\mathrm{H}^{+} \\
\mathrm{O}_{2}{ }^{\bullet-}+\mathrm{H}^{+} \rightarrow \mathrm{HO}_{2}
\end{gathered}
$$

Light excitation on catalysts leads to faster pathogen inactivation compared to runs in the dark. This is due to the additional release of ${ }^{\bullet} \mathrm{OH}$ radicals as suggested next in the reaction (11)

$$
\begin{gathered}
\mathrm{AgOH}+\text { light } \rightarrow \mathrm{Ag}^{\bullet}+{ }^{\bullet} \mathrm{OH} \\
\mathrm{e}^{-}+\mathrm{O}_{2}+\mathrm{H}+\rightarrow \mathrm{HO}_{2}{ }^{\bullet} \mathrm{E}_{0}-0.05 \mathrm{~V} \text { vs. NHE } \\
\mathrm{e}^{-}+\mathrm{O}_{2 \text { ads }} \rightarrow \mathrm{O}_{2}{ }^{-} \text {ad } \mathrm{E}_{0}-0.16 \mathrm{~V} \text { vs. NHE } \\
\mathrm{h}^{+}+\mathrm{OH}^{-}{ }_{\text {ads }} \rightarrow{ }^{\bullet} \mathrm{OH} \mathrm{E} \mathrm{E}_{0}-1.90 \mathrm{~V} \text { vs. NHE } \\
\mathrm{h}^{+}+\mathrm{H}_{2} \mathrm{O}_{\text {ads }} \rightarrow \mathrm{OH}_{\text {ads }}+\mathrm{H}^{+}
\end{gathered}
$$

The Langmuir-Hinshelwood (L-H) kinetic model is frequently employed to describe bacterial inactivation kinetics [6,7]. This model is applied to process the data obtained during virus inactivation mediated by $\mathrm{TiO}_{2}$ and metal- $\mathrm{TiO}_{2}$ photocatalysts [5-8]. In the $\mathrm{L}-\mathrm{H}$ model, the reactants are adsorbed and considered in equilibrium with the catalysis surface. This model assumes (a) that the system is in a steady state, (b) that the product formation is the rate limiting step, (c) that the products desorb quickly after the reaction and, finally, (d) that one of the reactants is present in a large excess. Viruses are made up of complex structures, presenting features that differ from chemical compounds, and the L-H model does not take into account the complexities of viruses. Any description of virus inactivation kinetics by this approach is not possible.

\section{IFCT-Mediated $\mathrm{TiO}_{2} / \mathrm{Cu}$ Bacterial/Virus Inactivation}

$\mathrm{TiO}_{2} / \mathrm{Cu}$ inactivation of pathogens was first reported by a Sunada et al. [32]. Later, several laboratories reported $\mathrm{Cu}$ ions/ $\mathrm{Cu}$ composites leading to E. coli inactivation by Fenton-like reactions and ROS radicals and peroxides being generated and partly adsorbed on $\mathrm{TiO}_{2}$. Inactivation by $\mathrm{Cu}_{\mathrm{x}} \mathrm{O}$ and $\mathrm{TiO}_{2} / \mathrm{Cu}$ films has been the focus of some recent reports [33-35]. $\mathrm{TiO}_{2} / \mathrm{Cu}$ lead to a higher degree of cell inactivation compared to $\mathrm{TiO}_{2}$ due to the $\mathrm{Cu}$ toxicity and the additional ROS generation detected in the solution compared to bare $\mathrm{TiO}_{2}$.

Why does doping enhance $\mathrm{TiO}_{2} / \mathrm{Cu}$ photocatalytic disinfection? $\mathrm{Cu}$ improves the $\mathrm{TiO}_{2}$ photocatalytic pathogen inactivation compared with $\mathrm{TiO}_{2}$ alone considering the following parameters: (a) the biocidal nature of $\mathrm{Cu}$ and (b) the shift of the NPs' absorption to the visible region up to $600 \mathrm{~nm}$. $\mathrm{TiO}_{2}$, absorbing around $4-4.5 \%$ of the solar irradiation, has been widely reported to activate pathogen inactivation processes. The bacterial protein for many pathogens absorbs light at up to $320-325 \mathrm{~nm}[36,37]$; (c) the $\mathrm{TiO}_{2}$ band gap is made narrower by the added $\mathrm{Cu} / \mathrm{CuO}$ and (d) the $\mathrm{Cu}$ clusters on $\mathrm{TiO}_{2}$ as electron traps hinder, to some extent, $\mathrm{e}-/ \mathrm{h}+$ recombination [38], and this occurs in conjunction with the charge transfer between the $\mathrm{TiO}_{2} / \mathrm{Cu}$ surfaces and the bacteria. A scheme for the IFCT processes taking place is shown below in Figure 5 .

A simplified mechanism for bacterial/virus inactivation is suggested for $\mathrm{CuO}$ NPs in Equations (16)-(23) [33,34]. By the use of photon energies exceeding the $\mathrm{CuO}$ band gap, the photogenerated cbe- can react with $\mathrm{O}_{2}$, leading to the $\mathrm{ROS}_{2}{ }^{\bullet-}$ or alternatively reducing the $\mathrm{Cu}^{2+}$ to $\mathrm{Cu}^{+}$as noted below:

$$
\begin{gathered}
\mathrm{CuOcbe}+\mathrm{O}_{2} \rightarrow \mathrm{CuO}+\mathrm{O}_{2}^{-} \\
\mathrm{CuO}(2+) \text { cbe- } \rightarrow \mathrm{CuO}(1)\left(\mathrm{Cu}^{+}\right) \\
\mathrm{CuO}\left(\mathrm{Cu}^{+}\right)+\mathrm{O}_{2} \rightarrow \mathrm{CuO}\left(\mathrm{Cu}^{2+}\right)+\mathrm{O}_{2}^{-} \\
\mathrm{CuO}\left(\mathrm{Cu}^{+}\right) \rightarrow \mathrm{CuO}_{\text {vacancy }}+\mathrm{Cu}^{+}
\end{gathered}
$$


Sequentially, binary sputtered films of $\mathrm{Cu}$ on polyethylene terephthalate $\mathrm{CuOx} / \mathrm{TiO}_{2}$ PET under visible light promote the interfacial charge transfer (IFCT) of the cbe- from $\mathrm{Cu}_{2} \mathrm{Ocb}$ to $\mathrm{TiO}_{2} \mathrm{cb}$, as noted in Equation (21). Then, the $\mathrm{TiO}_{2} \mathrm{vbh}+$ holes with an appropriate positive potential oxidize bacteria, as shown below by Equation (23).

$$
\begin{gathered}
\mathrm{Cu}_{2} \mathrm{O}+\mathrm{hv}(\text { visible }) \rightarrow \mathrm{Cu}_{2} \mathrm{Ocbe}+\mathrm{Cu}_{2} \mathrm{Ovbh}+ \\
\mathrm{Cu}_{2} \mathrm{Ocbe}-+\mathrm{TiO}_{2} \rightarrow \mathrm{TiO}_{2}{ }^{-} \text {or }\left(\mathrm{Ti}^{3+}\right)+\mathrm{Cu}_{2} \mathrm{O} \\
\mathrm{TiO}_{2}{ }^{-}+\mathrm{O}_{2} \rightarrow \mathrm{TiO}_{2}+\mathrm{O}_{2}{ }^{-} \\
\mathrm{Cu}_{2} \mathrm{Ovbh}^{+}+\text {bacteria } \rightarrow \mathrm{CO}_{2}, \mathrm{H}_{2} \mathrm{O} \text {, inorganic } \mathrm{N}, \mathrm{S}+\mathrm{Cu}_{2} \mathrm{O}
\end{gathered}
$$

The bacteriophage $\mathrm{f} 2$ has been photocatalytically inactivated under visible light irradiation. The removal efficiency of the virus increased with catalyst concentration, light intensity and temperature and decreased at a higher initial virus concentration. Zheng et al. reported on $\mathrm{TiO}_{2}$ doped with non-noble metals able to inactivate virus under light irradiation [39]. Until now the role of metal-ions in photocatalytic viral disinfection have not been explored in a systematic, comprehensive and detailed way. Composite material semiconductors containing $\mathrm{Ag}$ and to a lesser extent $\mathrm{Cu}$ have shown to form plasmon under UV-visible light irradiation [40-42]. The plasmons play a significant role in bacteria and virus inactivation. This remains a task of the future and seems necessary to increase the virus inactivation kinetics. This is one of the critical issues hindering the commercial scale application of photocatalytic technology for disinfection purposes [43].

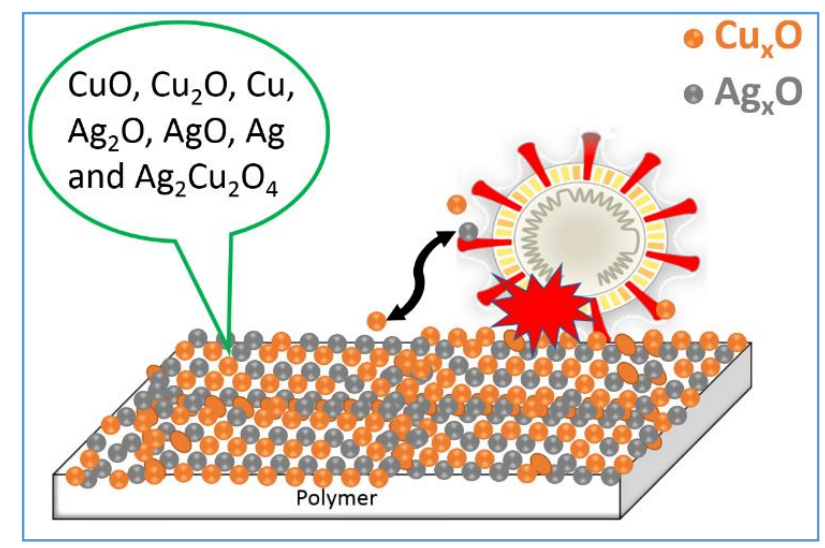

Figure 4. Schematic illustrating the species involved in virus inactivation in the dark or under light when composites made up of Ag-Cu were used as catalysts/photocatalysts.

\section{IFCT-Mediated Ag-Cu Bacterial/Virus Inactivation}

Studies on Ag-Cu NP films show higher bacterial inactivation kinetics compared to either $\mathrm{Ag}$ or $\mathrm{Cu}$ alone. Studies on $\mathrm{Ag}$-Cu NP films leading to the destruction of bacteria have been reported recently $[44,45]$. The composition and species found in these composites are shown in Figure 4.

The faster kinetic inactivation of pathogens by bimetallic/trimetallic oxides is used due to two main reasons: (a) it increases the absorption of semiconductors such as $\mathrm{TiO}_{2}$ into the visible range and (b) it also increases the number of potential couples available to catalyze/photocatalyze chemical transformations on the catalyst surface. Pathogen inactivation kinetics by bimetals such as Ag-Cu films compared to either $\mathrm{Ag}$ or $\mathrm{Cu}$ films by themselves. Work on Fe-doped/decorated wide-band semiconductors such as $\mathrm{TiO}_{2}$, mediating bacterial inactivation, has been reported recently [1]. Using fast kinetics spectroscopy, the short-lived precursors leading to bacterial inactivation have been sorted out $[43,46]$. 


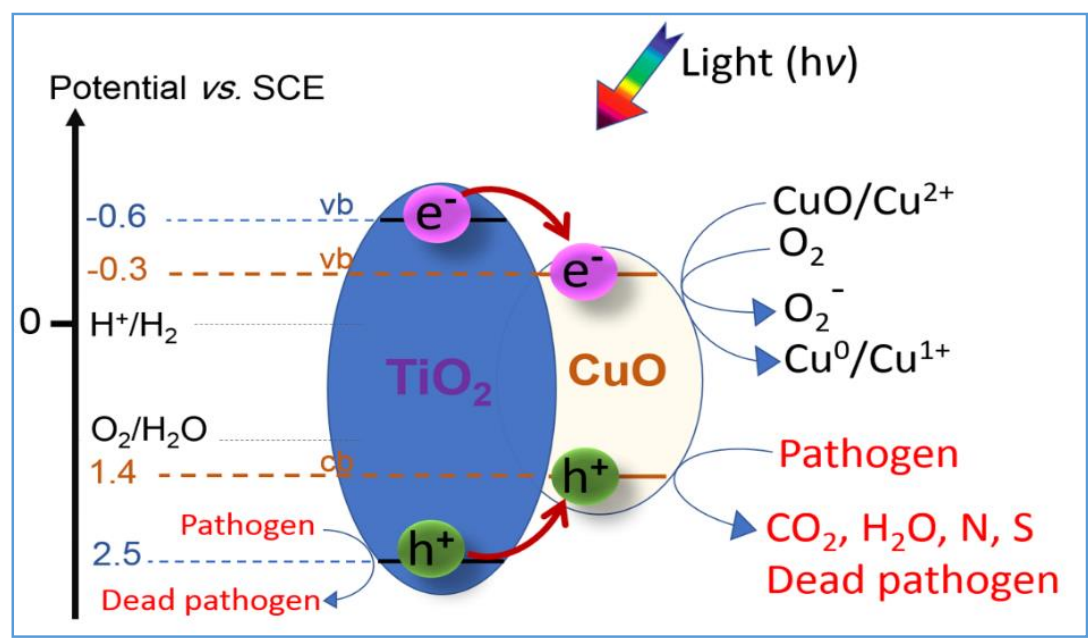

Figure 5. Interfacial charge transfer (IFCT) between $\mathrm{CuO}$ and $\mathrm{TiO}_{2}$ in $\mathrm{TiO}_{2} / \mathrm{CuO}$ nanoparticles (NPs), leading to the inactivation of pathogens in solution under visible light.

Killing bacteria on metallic copper surfaces occurs primarily due to the release of copper ions. However, it also involves slower processes such as the contact of the bacteria with the $\mathrm{Cu} / \mathrm{CuO}$ surface $[35,36]$. Copper cations participate in Fenton-like reactions, leading to fast cellular damage by ROS species in mammalian cell membranes. This is due to the high $\mathrm{Cu}$ cation cytotoxicity. There are no standard tests to evaluate NPs' cytotoxicity which may allow to compare the results found in different laboratories [47-49]. The translocation of $\mathrm{Cu}$ NPs/Cu ions and Ag ions into the pathogen cytoplasm is far from being understood at the present time. The relative index of the toxicity on mammalian cells of Ag NPs and $\mathrm{CuO}$ NPs is shown in Table 1 below. The parentheses show the number of experimental runs performed to report the median value.

Table 1. Mammalian cells in vitro relative cytotoxicity index.

\begin{tabular}{ccc}
\hline & Relative Index of Toxicity & $\begin{array}{c}\text { Number of Studies Used to Report } \\
\text { the Median Value }\end{array}$ \\
\hline $\mathrm{Ag} \mathrm{NPs}$ & 11 & $(25)$ \\
\hline $\mathrm{Ag}^{+}$ions & 2.0 & $(18)$ \\
\hline $\mathrm{CuONPs}$ & 25 & $(21)$ \\
\hline $\mathrm{Cu}^{2+}$ ions & 53 & $(10)$ \\
\hline
\end{tabular}

It is difficult to differentiate the toxicity introduced individually by $\mathrm{Ag}-\mathrm{Cu} \mathrm{NPs}$ surfaces and the separate effects induced by $\mathrm{Ag}$ and $\mathrm{Cu}$ NPs by themselves under light in aqueous media $[8,16,25]$. Recent studies indicated that $\mathrm{Cu}$ NPs induced oxidative damage to bacteria with higher kinetics compared to Ag NPs [24]. Figure 6 suggests the IFCT for $\mathrm{Ag}_{2} \mathrm{O} / \mathrm{CuO}$ composite films under light irradiation and the subsequent generation of radicals, leading to the degradation of organics $(\mathrm{RH})$ or bacteria.

Like many other metal film composites, Ag-Cu films accelerate the inactivation of pathogens $[50,51]$. This presents an alternative to the use of antibiotics without significantly increasing the risk of resistance when antibiotics are administered for long periods of time. The efficiency of these films is dependent on the coating technique used to prepare them. A more advanced nanotechnological approach to prepare uniform and reproducible NP polymer films would benefit the inactivation of pathogens within acceptable times $[52,53]$. The quantitative contribution of each NP to the production of reactive oxygen species is still an open issue. $\mathrm{Cu}$ (II) ions are reduced to $\mathrm{Cu}(\mathrm{I})$ ions by the enzymes regulating the human respiratory cycle [35]. An excess of copper cations cannot be removed by these enzymes [36] and leads to respiratory cycle disfunction and death within short times. 


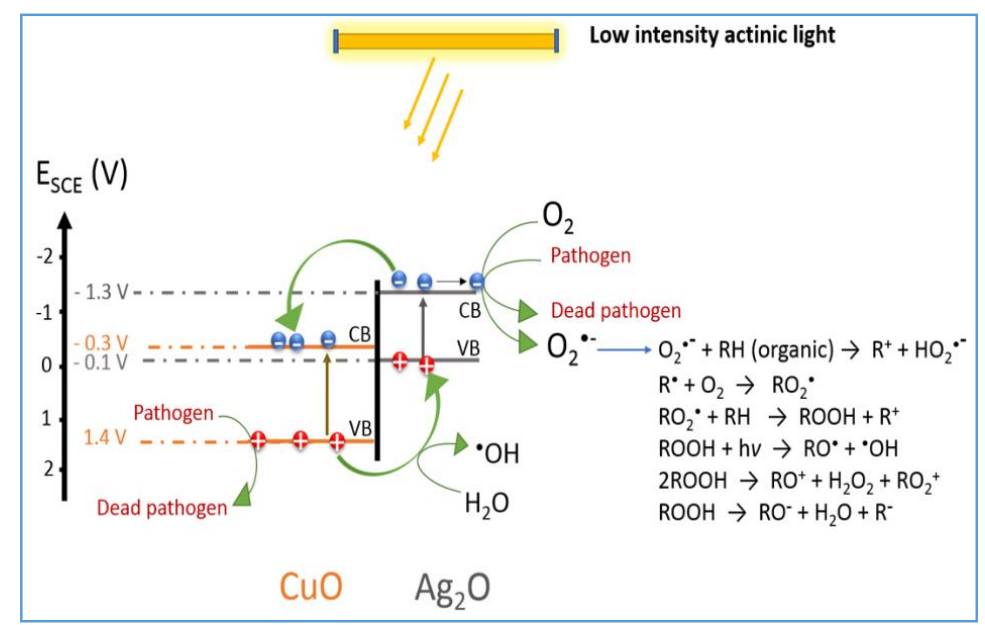

Figure 6. Interfacial charge transfer (IFCT) for $\mathrm{Ag}_{2} \mathrm{O} / \mathrm{CuO}$ composites under light doses of $<4 \mathrm{~mW} / \mathrm{cm}^{2}$, showing the generation of ROS, leading to the inactivation of pathogens under light irradiation and the potential energy level of both semiconductor components.

Surface plasmon resonance (SPR) bands have been investigated for some years for $\mathrm{Au}, \mathrm{Ag}$ and $\mathrm{Cu}$ nanoparticles. Cu SPR films are also applied in optical catalysis, detection and conductive devices used in printing technologies [52]. Until now, no comprehensive mechanism has been reported for the detailed intervention of $\mathrm{Cu}$ plasmons leading to bacterial/virus inactivation, and Au plasmons intervening in bacterial inactivation have recently been reported [43]. Visible light irradiation of $\mathrm{SPR} \mathrm{Au} / \mathrm{TiO}_{2}$ bands activates the electron injection of $\mathrm{Au}$ NPs into $\mathrm{TiO}_{2}$ with a slight dissolution of the $\mathrm{Au}$. This dissolution leads to (a) the injection of hot Au electrons into $\mathrm{TiO}_{2}$ followed by femtosecond spectroscopy and (b) the generation of $\mathrm{Au}$ ions in the solution [43]. This study also reports on $\mathrm{Au}$ ions' mechanism of interaction with bacterial cells. The bactericidal inactivation mechanism by $\mathrm{Au}$ ions is significantly different to the mechanism reported for Ag SPR and Cu SPR activated by light.

Higher toxicity has been extensively reported for $\mathrm{Cu}$ relative to Ag. Extremely low amounts of $\mathrm{Cu}$ species (in the nano range) induce pathogen inactivation in the dark due to the high cytotoxicity of $\mathrm{Cu}$ per unit weight compared to $\mathrm{Ag}$. $\mathrm{Cu}$ is not a noble metal and is readily available compared to $\mathrm{Ag}$. This makes $\mathrm{Cu} / \mathrm{CuO} / \mathrm{Cu}$ ions a preferred choice for pathogen inactivation studies. Copper is number 29 of the periodic table of elements. The $\mathrm{Cu}$ atomic structure is made up of negatively charged electrons in completely filled orbitals close to the positively charged atomic nucleus. The electrons of the unfilled orbitals $4 s^{1} 3 d^{10}$ require a small input of energy to activate chemical reactions. $\mathrm{Cu}(\mathrm{I})\left(4 \mathrm{~s}^{0} 3 \mathrm{~d}^{10}\right)$ and $\mathrm{Cu}(\mathrm{II})\left(4 \mathrm{~s}^{0} 3 \mathrm{~d}^{9}\right)$ oxidation states require a much lower one-electron redox potential compared to $\mathrm{Ag}(\mathrm{I}) / \mathrm{Ag}(\mathrm{II})$ and $\mathrm{Fe}(\mathrm{II}) / \mathrm{Fe}$ (III) in electron transfer reactions. Gram-negative bacteria including $\mathrm{Cu}$ in the periplasm can handle the toxicity of copper cations up to a certain level in their own metabolism.

\section{IFCT in $\mathrm{Fe}_{2} \mathrm{O}_{3} / \mathrm{TiO}_{2}$ Giving Rise to Fenton-Like Reactions Mediating Virus/Bacterial Inactivation}

$\mathrm{Fe}_{2} \mathrm{O}_{3}-\mathrm{TiO}_{2}$ double oxides have been reported to induce a more accelerated photocatalysis compared to bare $\mathrm{Fe}_{2} \mathrm{O}_{3}$ under visible light. This is due to the presence of the $\mathrm{Fe}_{2} \mathrm{O}_{3}-\mathrm{TiO}_{2}$ heterojunction, in which $\mathrm{Fe}_{2} \mathrm{O}_{3}$ acts as the $\mathrm{TiO}_{2}$ photosensitizer under visible light. Figure 7 presents a schematic for the $\mathrm{Fe}_{2} \mathrm{O}_{3}-\mathrm{TiO}_{2}$ intervention [54]. The conduction band (cb) of $\mathrm{Fe}_{2} \mathrm{O}_{3}$ is located at a lower potential energy level with respect to $\mathrm{TiO}_{2}$, as shown in Figure 7. However, electron transfer is possible since the $\mathrm{TiO}_{2}$ lattice presents trapping sites $\sim 0.8 \mathrm{eV}$ below the position of the $\mathrm{TiO}_{2} \mathrm{cb}[4,55,56]$. The charge transfer between the two semiconductors led to (a) an increase in the photogenerated charge separation in $\mathrm{Fe}_{2} \mathrm{O}$, (b) an increase in the pollutant oxidation kinetics by the generated holes and (c) improved 
reduction kinetics of the $\left(\mathrm{O}_{2}\right)_{\text {air }}$ by the photogenerated $(\mathrm{cb})$ electrons. The $\mathrm{TiO}_{2}$ vb generates the $\bullet \mathrm{OH}$ radicals leading to bacterial/virus inactivation due to the more favorable potential energy position of its $\mathrm{vb}$. The charge transport in the $\mathrm{Fe}_{2} \mathrm{O}_{3}-\mathrm{TiO}_{2}$ controls the photocatalytic-mediated reaction kinetics [57-60]. Under light, the $\mathrm{Fe}^{2+}$ in the $\mathrm{Fe}_{2} \mathrm{O}_{3}-\mathrm{TiO}_{2}$ undergoes a redox reaction and oxidizes to $\mathrm{Fe}^{3+}$, as noted in Equation (24) below:

$$
\mathrm{Fe}^{2+}+\mathrm{Ti}^{4+} \rightarrow \mathrm{Fe}^{3+}+\mathrm{Ti}^{3+}
$$
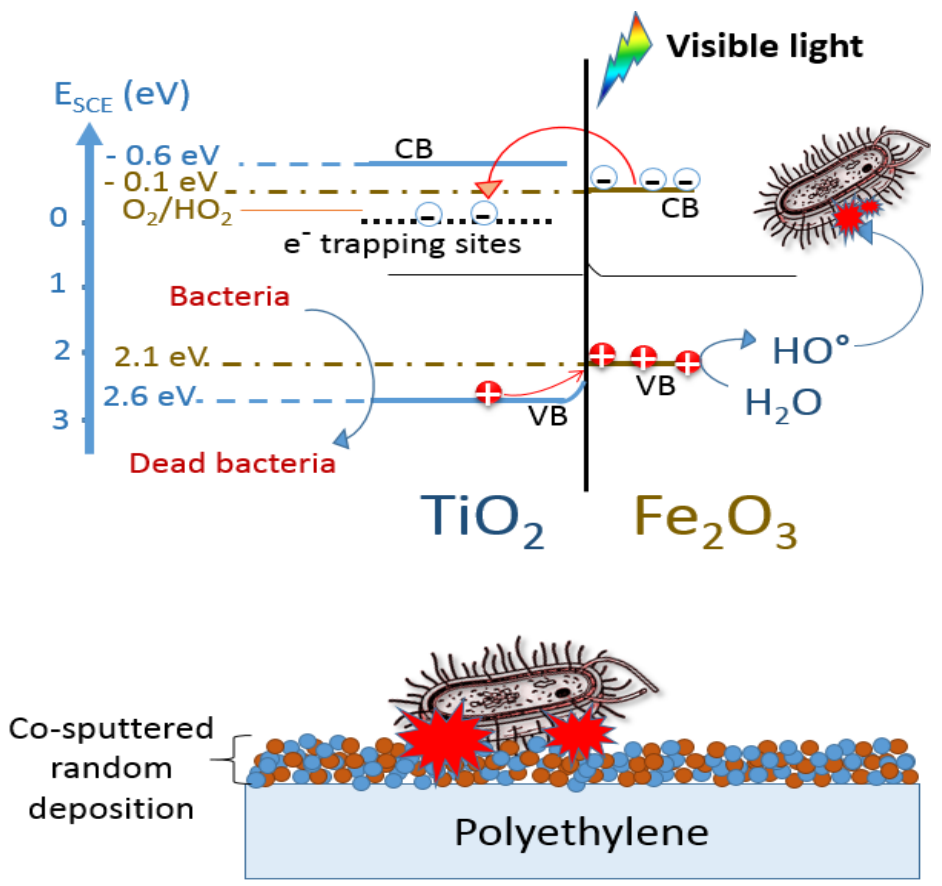

Figure 7. Mechanism suggested for bacterial inactivation by co-sputtered by $\mathrm{FeOx}-\mathrm{TiO}_{2}-\mathrm{PE}$ films under visible light, showing the IFCT process taking place between $\mathrm{Fe}_{2} \mathrm{O}_{3}$ induced by visible light.

The schema in Figure 8 suggests that with the $\mathrm{FeOx} / \mathrm{TiO}_{2}-\mathrm{PE}$, bacterial inactivation on the film is possible from the $\mathrm{Fe}$ oxide into $\mathrm{TiO}_{2}$ due to low-lying states detected below the conduction band $(\mathrm{cb})$ of $\mathrm{TiO}_{2}$. This allows to suggest a scheme of reactions leading to a short-lived unstable bacteria cation(+) as noted below in Equation (25) and reported in reference [43].

Bacteria $+[$ PE-FeOx $]+$ Vis light $\rightarrow\left[\right.$ Bacteria $^{*} \ldots$ FeOx $] \mathrm{PE} \rightarrow\left[\right.$ Bacteria $^{+} \ldots$ FeOx cbe $] \mathrm{PE}$

During the bacterial abatement process shown in Figure 7, some Fe ions leach out of the $\mathrm{FeOx}-\mathrm{TiO}_{2}-\mathrm{PE}$ films under light irradiation in an aqueous solution. This gives rise to Fenton-like reactions with ions such as $\mathrm{Fe}, \mathrm{Mn}$ or $\mathrm{Cu}$ ions [20]. ROS radicals are generated in solution [20]. The reaction sequence leading to virus/bacterial inactivation proceeds through several steps as detailed next: (a) virus adsorption on the catalyst; (b) ROS generation and surface and bulk reactions and (c) desorption of the inactivated viruses. The diffusion of the virus within the inoculate plays a role in the inactivation process [9]. Mononuclear metalloenzymes include Fe(II) in their structure since Fe ions are important in human/animal metabolism. These mononuclear Fe enzymes are made up of Fe and $\mathrm{Zn}$ (II) and Mn(II). Fenton chemistry occurs when FeOx corrodes, leading to Fe ions in solution [61]. Fe enzyme Fe-S dehydratase such as $\mathrm{Fe}(\mathrm{II})$-cysteine is oxidized through Fenton reactions to the sulphinic $\mathrm{RSO}(=\mathrm{H})$ or sulphonic $\mathrm{RS}=\mathrm{O}_{2}-\mathrm{OH}$ species, displacing $\mathrm{Fe}(\mathrm{II})$ from the metalloenzyme. The latter reaction involves several steps: (a) oxidant depletion and (b) additional (excess) ROS and thiol depletion from the cell bilayer topmost functional groups [62]. Thiol depletion due to Fenton-like reactions is shown schematically 
in Figure 9. The outcome is that normal cell metabolism is inhibited, leading to cell death. Fe-S-type dehydratases are particularly sensitive to the destruction of the topmost bilayer functional binding groups containing S-moieties [63].

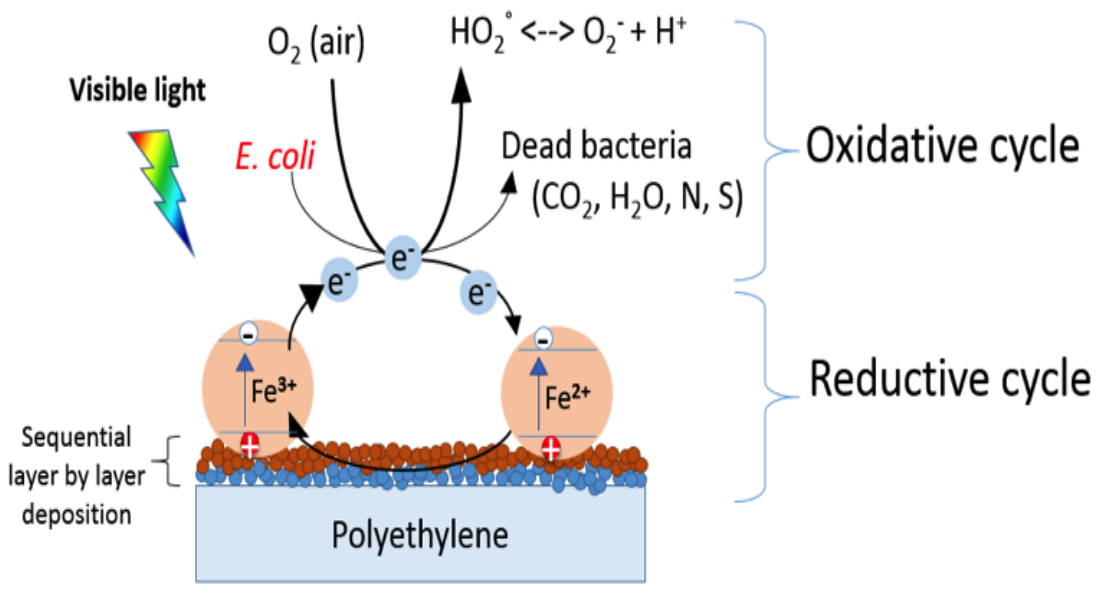

Figure 8. Mechanism suggested for bacterial inactivation mediated by sequentially sputtered polyethylene films $\left(\mathrm{FeOx} / \mathrm{TiO}_{2}-\mathrm{PE}\right)$ films under visible light.

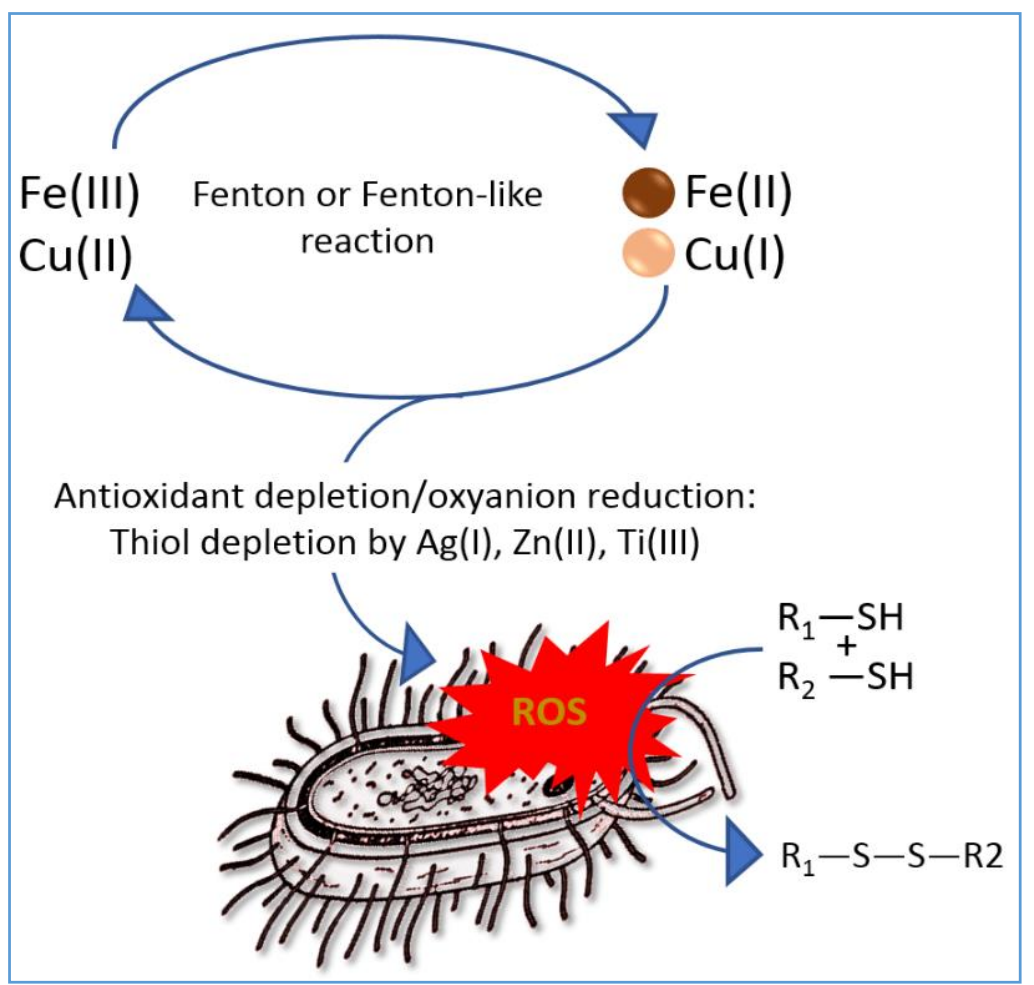

Figure 9. Schematic of Fenton chemistry due to ions of $\mathrm{Fe}(\mathrm{III})$ or $\mathrm{Cu}(\mathrm{II})$ associated with ROS intermediates leading to thiol depletion in the bacteria and virus topmost layers.

When the Fenton reagent $\left(\mathrm{Fe}^{2+}+\mathrm{H}_{2} \mathrm{O}_{2}\right)$ is added in solution, an increase in the $\mathrm{OH}$ radicals is observed compared to solutions with only added $\mathrm{H}_{2} \mathrm{O}_{2}$. This is due to the fine dispersion of nanosized Fe NPs leaching out Fe ions during the partial dissolution of the Fe NPs. The catalytic species $\mathrm{Fe}\left(\mathrm{H}_{2} \mathrm{O}\right)_{6}{ }^{*}$ in solution with a lifetime $<1$ ns induce peroxide decomposition in solution in the dark and more so under visible band-gap light irradiation (Haber-Weiss-related type of reactions). The concentration of $\mathrm{OH}$ radicals when an organic 
compound (RH) with a concentration of $10^{-3} \mathrm{M}$ is added to a solution made up of $\mathrm{Fe}^{2+/ 3+}$ $10^{-3} \mathrm{M}$ and $\mathrm{H}_{2} \mathrm{O}_{2} 10^{-2} \mathrm{M}$ can be estimated from the reactions:

$$
\begin{array}{cc}
\mathrm{Fe}^{2+}+\mathrm{H}_{2} \mathrm{O}_{2} \rightarrow \mathrm{Fe}^{3+}+\mathrm{OH}^{-}+\bullet \mathrm{OH} & \mathrm{k}_{1}(40-60) \mathrm{M}^{-1} \cdot \mathrm{s}^{-1} \\
\bullet \mathrm{OH}+\mathrm{RH} \rightarrow \mathrm{H}_{2} \mathrm{O}+\mathrm{R} & \mathrm{k}_{2} 610^{9} \mathrm{M}^{-1} \cdot \mathrm{s}^{-1}
\end{array}
$$

$\mathrm{d}(\mathrm{OH}) / \mathrm{dt}=\mathrm{k}_{1} \mathrm{Fe}\left(\mathrm{Fe}^{2+}\right)\left(\mathrm{H}_{2} \mathrm{O}_{2}\right)-\mathrm{k}_{2}(\bullet \mathrm{OH})(\mathrm{RH})$ is $\sim 0$, a quasi-stationary state, since the concentration of $\mathrm{OH}^{\cdot}$ is very small. The $\mathrm{OH}$ radical is generated in sub-nanomolar concentrations as shown by the equation $\left({ }^{\bullet} \mathrm{OH}\right)=\mathrm{k}_{1}\left(\mathrm{Fe}^{2+}\right)\left(\mathrm{H}_{2} \mathrm{O}_{2}\right) / \mathrm{k}_{2}(\mathrm{RH})$ in quantities of about $\sim 10^{-10} \mathrm{M}$. This latter value corresponds to a sub-nanomolar concentration. The concentration estimated for the $\mathrm{OH}$ radicals is similar to the concentration of $\mathrm{OH}$ radicals found in many natural water bodies.

\section{IFCT in Ternary Semiconductors Leading to Bacterial/Virus Inactivation}

A mechanism is suggested in Figure 10a for the interfacial charge transfer (IFCT) in the $\mathrm{Ag}(3 \%)-\mathrm{TiO}_{2}-\mathrm{FeO}_{\mathrm{x}}(3 \%)$ photocatalyst mediating bacterial inactivation [64]. The $\mathrm{TiO}_{2} \mathrm{cb}$ position in $\mathrm{Ag}(3 \%)-\mathrm{TiO}_{2}-\mathrm{FeO}_{\mathrm{x}}(3 \%)$ is more cathodic compared to $\mathrm{FeO}_{\mathrm{x}} \mathrm{cb}$, and the $\mathrm{TiO}_{2} \mathrm{vb}$ is more anodic in respect to $\mathrm{FeO}_{x}$. The potential energy positions of the potential electronic bands of the three oxides determine the IFCT kinetics taking place in Figure 10a. The release of Fe-ions in aqueous solutions by the magnetic $\mathrm{Ag}(3 \%)-\mathrm{TiO}_{2}-\mathrm{FeO}_{\mathbf{x}}(3 \%)$ composite has been reported for several years when using Fe-composites. In the case of the $\mathrm{Ag}(3 \%)$ $\mathrm{TiO}_{2}-\mathrm{FeO}_{\mathrm{x}}(3 \%)$, a high calcination temperature was used during the preparation of this composite. The calcination step strongly binds the $\mathrm{Fe}$ to the $\mathrm{TiO}_{2}$ through $\mathrm{Ti}-\mathrm{OH}$ bonds. This precludes the Fe-ions release into solution within the bacterial inactivation process. The $\mathrm{FeO}_{\mathrm{x}}$ (mainly $\mathrm{Fe}_{2} \mathrm{O}_{3}$ ) in the $\mathrm{Ag}(3 \%)-\mathrm{TiO}_{2}-\mathrm{FeO}_{\mathrm{x}}(3 \%)$ during the calcination step becomes deeply buried in the catalyst bulk. If present in the surface, the $\mathrm{FeOx}$ would photo-corrode in aqueous media under light irradiation [65]. The significant acceleration in the bacterial inactivation kinetics by $\mathrm{Ag}(3 \%)-\mathrm{TiO}_{2}-\mathrm{FeO}_{\mathrm{x}}(3 \%)$ is due to the localized electric field leading to more reactions per unit time compared to the non-magnetized catalyst $\mathrm{Ag}(3 \%)-\mathrm{TiO}_{2}$. This leads to the polarization in the $\mathrm{Ag}(3 \%)-\mathrm{TiO}_{2}-\mathrm{FeO}_{\mathrm{x}}(3 \%)$ heterojunction enhancing the separation of electrons and holes [66]. Repetitive recycling of the $\mathrm{Ag}(3 \%)-\mathrm{TiO}_{2}-\mathrm{FeO}_{\mathbf{x}}(3 \%)$ did not lead to loss of catalytic activity. This provides evidence for the stable nature of the $\mathrm{FeO}_{\mathrm{x}}$ present in the composite photocatalyst.

The use of heterostructures made up by wide-band semiconductors, oxide and metals reduces the band gap of $\mathrm{TiO}_{2}(\mathrm{bg} 3.2 \mathrm{eV})$. As a result, development of visible light active titanium dioxide materials was observed. This is one of the main challenges in the field of semiconductor photocatalysis. Heterostructures composed of ternary catalysts, doped or not, enhance light absorption in the visible region. Figure 10b shows an example of IFCT over ternary semiconductor photocatalysts. More work to identify appropriate dopants to improve visible light absorption and electron-hole separation is needed at this time to enhance photocatalytic activity. One serious problem encountered in binary or ternary semiconductors designed to accelerate bacterial/virus inactivation is the electrostatic recombination of the cbe- of one semiconductor with the vbh+ holes of the other semiconductor. This hinders the diffusion of photogenerated charges to the semiconductor surface, lowering the production of readily available photogenerated species [67].

Other compounds presenting heterostructures with a $\mathrm{TiO}_{2}$ component, leading to bacterial inactivation, have recently been reported such as $\mathrm{C} 70-\mathrm{TiO}_{2}$ [68], $\mathrm{TiO}_{2} / \mathrm{Ag}_{3} \mathrm{PO}_{4}$ [69], $\mathrm{TiO}_{2}$-graphene [70], $\mathrm{TiO}_{2}-\mathrm{MWCNT}$ [71] and $\mathrm{TiO}_{2}$-graphene [72]. The inactivation of bacteria by other composites involving IFCT processes has also been described in the open literature [73-78]. The photocatalytic inactivation of staphylococcus, streptococcus and fungi can be found in references [79-83].

Semiconductors have many advantages over nanoparticle dispersions or colloidal dispersions in photocatalytic reactions activated by solar/visible light irradiation. Long et al. [84] reported on the beneficial effect of intrinsic structural defects in a semicon- 
ductor on their chemical reactivity. This affects the stability and electronic properties of semiconductors. In some cases, these defects enhance the potential energy position of the semiconductor electronic bands. Fu et al. recently reported that the photocatalytic efficiency of a semiconductor varied with the type of defects in the composite, whether it was a surface, bulk or adsorbate defect. Defects modify the semiconductor band bending and, therefore, the semiconductor electronic structure. Both factors introduce changes in the semiconductor IFCT process mediating the chemical transformation. The potential to improve semiconductor performance by the introduction of adequate defects in the semiconductor structure is important for any future application of semiconductor devices.

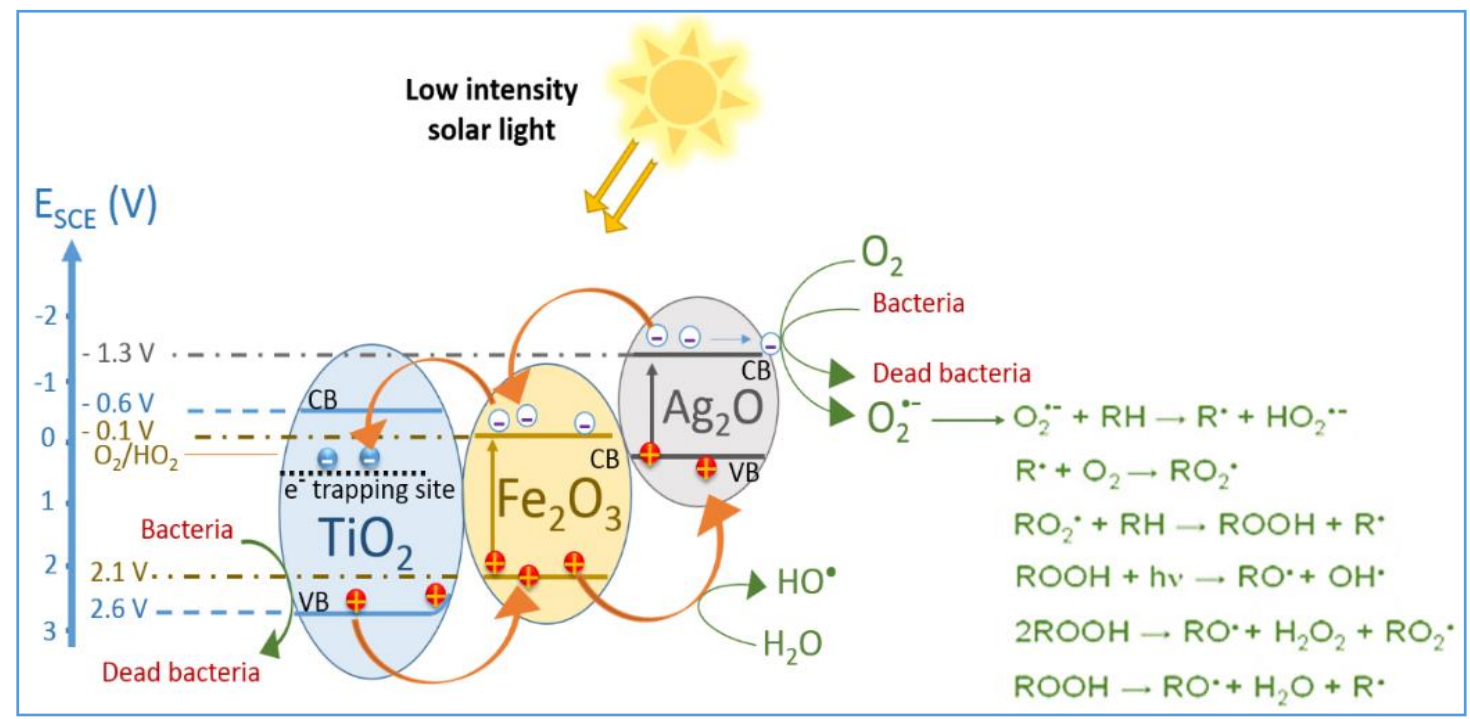

(a)

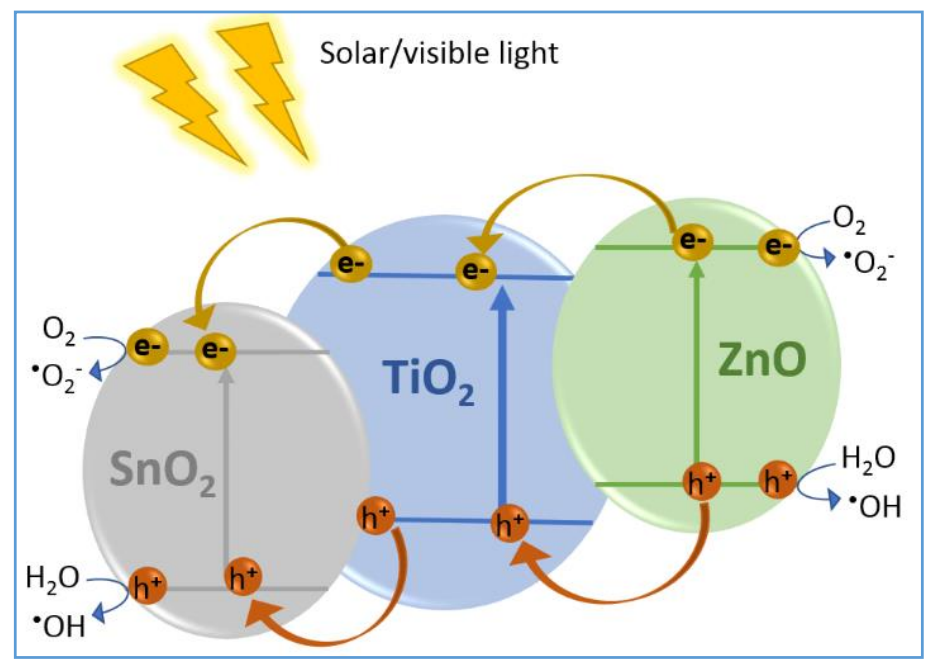

(b)

Figure 10. (a) $\mathrm{Ag}(3 \%)-\mathrm{TiO}_{2}-\mathrm{FeOx}(3 \%)$ ternary photocatalyst being irradiated by visible light. The interfacial charge transfer (IFCT) within the composite photocatalyst is shown as a function of their relative potential energy levels leading to the bacterial inactivation process. (b) IFCT and electron transfer mechanism for the stable ternary semiconductor photocatalyst made up of $\mathrm{TiO}_{2} / \mathrm{SnO}_{2} / \mathrm{ZnO}$.

\section{Viral Biofilms}

Biofilms are aggregates of bacteria/viruses on a surface surrounded by a protective coating that keep for long times on surfaces. They have been recognized as the most effec- 
tive way of spreading dangerous pathogens into the environment. Biofilms induce diseases that account for more than $80 \%$ of viral/bacterial infections. The biofilms once anchored on supports are resistant to their removal by conventional antiseptics or disinfectants. Viruses are capable of forming complex biofilm-like assemblies, similar to bacterial biofilms, and disseminate viruses dangerous pathogens into the environment for long periods of time, especially within hospitals and healthcare facilities, depending on local conditions. Biofilms are usually resilient to stress, lack of water, $\mathrm{pH}$ effects and mechanical stress or impacts. The stages of biofilm formation are schematically suggested in Figure 11 [85].

(a) Biofilm formation: The first stage in biofilm formation is the adhesion of a virus on a surface by adsorption, involving hydrophobic effects through covalent bonding. Roughness of the surface favors this step and avoids liquids flowing near the biofilms to preclude biofilm formation. The second stage involves bacteria reproduction to form a colony matrix, with this step being concomitant to the growth of an extracellular polymeric shell protecting the colony. In the third/last step, the colony attains its critical mass, ingests nutrients and eliminates metabolic residuals with a kinetics regulated by its enzymes [86].

(b) The degradation of recalcitrant biofilms occurs in different ways and is suggested next in Figure 12, involving several steps: (a) surface structural modification to preclude biofilm adhesion; (b) the use of bactericidal agents inducing quorum quenching/enzymatic/immunological disruption and (c) the use of catalysts under light or in the dark, leading to bacterial interference in the biofilm [87]. Biofilm destruction is important since many films are resilient to degradation by antibiotic metal/oxide or chloro-compounds. Human coronavirus ( $\mathrm{HCoV})$ films lead to respiratory diseases [38]. $\mathrm{TiO}_{2} / \mathrm{Ag}, \mathrm{TiO}_{2} / \mathrm{Cu}$ and $\mathrm{TiO}_{2} / \mathrm{Fe}_{2} \mathrm{O}_{3}$ composites under light irradiation involving IFCT processes have been discussed above in this study and illustrated with a few relevant examples.

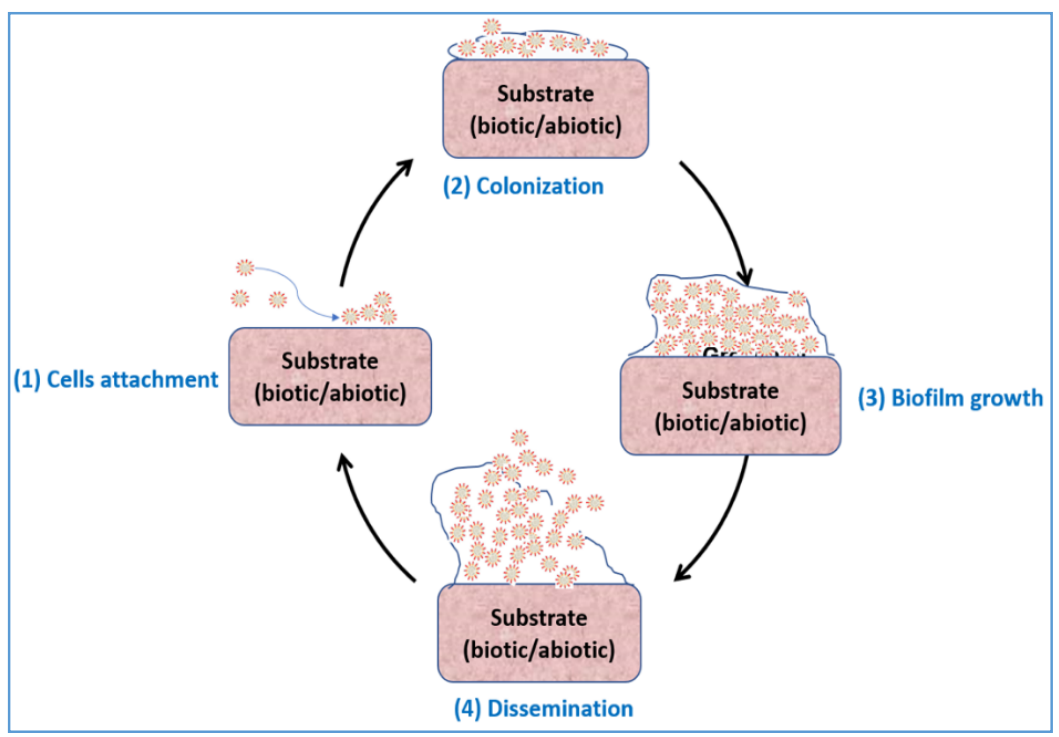

Figure 11. Growth of a virus biofilm. Initially, viruses settle down onto a surface that can either be inanimate or living tissue. Then, secretion of extracellular matrix allows the cells to colonize and anchor on the substrate. This step repeats itself, leading to biofilm growth. Finally, a fully developed biofilm with water channels allows oxygen and nutrients to penetrate to the biofilm and allows processes disseminating viruses into the environment for a long time. 


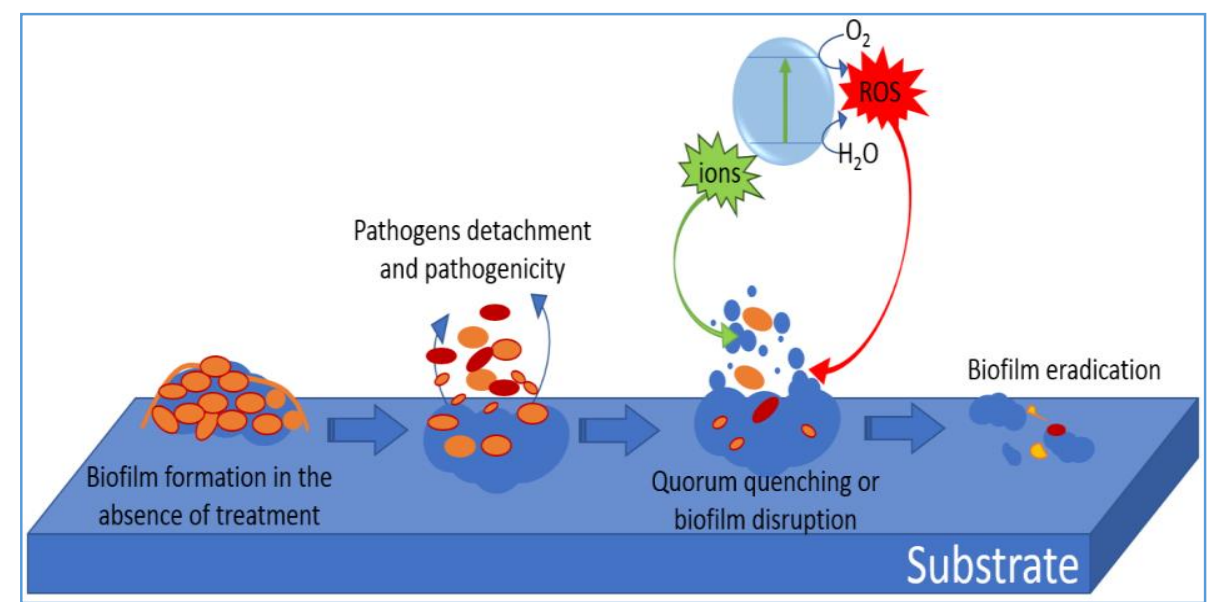

Figure 12. Strategies to neutralize the damage of toxic films spreading pathogens into the environment.

\section{Conclusions and Outlook for Future Work}

This update briefly describes the scientific bases for the use of semiconductor and metal/semiconductor materials, addressing critical issues in the photocatalytic pathogen inactivation field. Some fundamental issues related to the inactivation of pathogens by materials under visible light irradiation were summarily described. The advantages and limitations of these innovative materials leading to pathogen inactivation are briefly described. The advantages of photochemical processes in bacterial/virus disinfection compared to the use of chlorinated compounds were addressed in detail. The objective of this update was to guide the readership working in microbiology and photocatalysis on disinfection by a mild and environmentally friendly technique.

Future work should address the synthesis of innovative, better performing catalysts. These materials may be applied in conjunction with oxidants commonly present in water reservoirs such as $\mathrm{H}_{2} \mathrm{O}_{2}$ /organic peroxides. The virus inactivation kinetics of supported films has been reported to be below the one found for clusters/colloids/powders. This is due to the lower surface area available in the film compared to dispersions. However, microparticles dissolved in solution have to be separated after the disinfection process. This is not the case for bactericide films. Films presenting high adsorption for bacteria/viruses could remove this disadvantage and enable their use in photoreactors, useful in continuous processes.

Little is known, to date, on the subject of the viral disinfection kinetics mechanism. Virus disinfection kinetics does not follow the first-order kinetics reported for organic pollutant degradation induced by $\mathrm{TiO}_{2}$ under light irradiation. This is due to the more complicated viral structure, envelope and repair mechanisms against ROS damage. Much of the present work to inactivate viruses by photocatalytic treatment follows the approach used to inactivate bacteria. However, the structure, surface, size, hydrophobic balance and redox properties of viruses are quite different to those found in bacteria. Innovative materials should be biocompatible, stable and present during long operational times and should present an acceptable corrosion resistance. This enables the release of NPs into solution within the threshold fixed by sanitary regulations. Novel $\mathrm{Cu}$ disinfection materials precluding $\mathrm{Cu}$ release from the matrix should be designed but should still present contact catalytic sites on their surface that are able to inactivate pathogens. A precedent for this type of material is the case of Fe catalysts/photocatalysts, proceeding without the release of $\mathrm{Fe}$ - from $\mathrm{TiO}_{2}$ matrixes [54]. Future research should address the synthesis of more advanced double metal oxides and other composites made up of biocompatible metal/ions with high redox potentials such as $\mathrm{Ag}, \mathrm{Mn}, \mathrm{Fe}$ and $\mathrm{Au}$ compared to traditional semiconductors such as $\mathrm{TiO}_{2}, \mathrm{ZnO}$ and $\mathrm{MnO}_{2}$. Controlled release of metals/ions in sub-nanomolar amounts into water bodies has not been addressed, until now, to induce virus inactivation. 
Author Contributions: S.R. and J.K. contributed equally to the formulation of the text and figures presented in this update. All authors have read and agreed to the published version of the manuscript.

Funding: This research received no external funding.

Conflicts of Interest: The authors declare no conflict of interest.

\section{References}

1. Pelaez, M.; Nolan, N.T.; Pillai, S.C.; Seery, M.K.; Falaras, P.; Kontos, A.G.; Dunlop, P.S.M.; Hamilton, J.W.J.; Byrne, J.A.; O’Shea, K.; et al. A review on the visible light active titanium dioxide photocatalysts for environmental applications. Appl. Catal. B Environ. 2012, 125, 331-349. [CrossRef]

2. Doll, M.; Stevens, M.; Bearman, G. Environmental cleaning and disinfection of patient areas. Int. J. Infect. Dis. 2018, 67, 52-57.

3. Schneider, J.; Matsuoka, M.; Takeuchi, M.; Zhang, J.L.; Horiuchi, Y.; Anpo, M.; Bahnemann, D.W. Understanding TiO 2 photocatalysis: Mechanisms and materials. Chem. Rev. 2014, 114, 9919-9986. [CrossRef] [PubMed]

4. Rtimi, S. Indoor light enhanced photocatalytic ultra-thin films on flexible non-heat resistant substrates reducing bacterial infection risks. Catalysts 2017, 7, 57. [CrossRef]

5. Kubacka, A.; Diez, M.; Rojo, D.; Bargiela, R.; Ciordia, S.; Zapico, I.; Albar, J.; Barbas, C.; dos Santos, V.M.; Fernandez-Garcia, M.; et al. Understanding the antimicrobial mechanism of $\mathrm{TiO}_{2}$ based nanocomposite films in a pathogenic bacterium. Sci. Rep. 2014, 14, 4134-4143. [CrossRef] [PubMed]

6. Yemmireddy, V.K.; Hung, Y.-C. Using photocatalyst metal oxides as antimicrobial surface coatings to ensure food safety, opportunities and challenges, comprehensive revs. Food Sci. Technol. 2017, 16, 617-631.

7. Kara, L.; Boehm, L.B.; Davies-Colley, J.; Dodd, C.; Kohn, T.; Linden, G.; Karl, G.; Liu, Y.; Maraccini, A.; McNeill, K. Sunlightmediated inactivation of health-relevant microorganisms in water: A review of mechanisms and modeling approaches. Environ. Sci. Process. Impacts 2018, 20, 1089-1122.

8. Gomes, J.; Matos, A.; Gmurek, M.; Quinta-Ferreira, R.M.; Martins, R.C. Ozone and photocatalytic processes for pathogens removal from water: A review. Catalysts 2019, 9, 46. [CrossRef]

9. Byrne, G.; Subramiam, C.; Pillai, S.C. Recent advances in catalysis for photochemical applications. Environ. Chem. Eng. 2018, 6, 3531-3555. [CrossRef]

10. Laxma Reddy, K.P.V.; Kumar, B.; Reddy, P.A.; Kimd, K.-H. Environmental research $\mathrm{TiO}_{2}$-based photocatalytic disinfection of microbes in aqueous media. Environ. Res. 2018, 154, 296-303. [CrossRef]

11. Park, G.W.; Cho, M.; Cates, E.L.; Lee, D.; Oh, B.T.; Vinje, J. Fluorinated $\mathrm{TiO}_{2}$ as an ambient light-activated virucidal surface coating material for the control of human norovirus. J. Photochem. Photobiol. B 2014, 140, 315-320. [CrossRef] [PubMed]

12. Singh, P.; Borthakur, A.; Mishra, P.K.; Tiwary, D. (Eds.) Nanomaterials as Photocatalysts for Degradation of Environmental Pollutants; Elsevier: Amsterdam, The Netherlands, 2020; ISBN 978-0-12-818598-8.

13. Kanan, S.; Moyet, M.; Arthur, R.; Patterson, H. Recent advances on $\mathrm{TiO}_{2}$-based photocatalysts toward the degradation of pesticides and major organic pollutants from water bodies. Catal. Rev. Sci. Eng. 2020, 62, 1-65. [CrossRef]

14. Calgua, B.; Carratalà, A.; Guerrero-Latorre, L.; de Abreu Corrêa, A.; Kohn, T.; Sommer, R.; Girones, R. UVC inactivation of dsDNA and ssRNA viruses in water: UV fluences and a qPCR-based approach to evaluate decay on viral infectivity. Food Environ. Virol. 2014, 6, 260-268. [CrossRef] [PubMed]

15. Wigginton, K.; Pecson, B.; Sigstam, T.; Bosshard, F.; Kohn, T. Virus inactivation mechanisms: Impact of disinfectants on virus function and structural integrity. Environ. Sci. Technol. 2012, 46, 12069-12078. [CrossRef] [PubMed]

16. Rai, M.; Desmukh, S.; Ingle, A.; Gupta, I.; Galdiero, M.; Galdiero, S. Metal-nanoparticles: The protective nano-shield against virus infection. Crit. Rev. Microb. 2016, 42, 45-56. [CrossRef] [PubMed]

17. Zhang, C.; Li, Y.; Shuai, D.; Shen, Y.; Wang, D. Progress and challenges in photocatalytic disinfection of waterborne viruses: A review to fill current knowledge gaps. Chem. Eng. J. 2019, 355, 399-415. [CrossRef]

18. Li, G.; Nie, X.; Chen, J.; Jiang, Q.; An, T.; Wong, H.P.; Zhang, H.; Zhao, H.; Yamashita, H. Enhanced visible-light-driven photocatalytic inactivation of Escherichia coli using $\mathrm{g}-\mathrm{C}_{3} \mathrm{~N}_{4} / \mathrm{TiO}_{2}$ hybrid photocatalyst synthesized using a hydrothermalcalcination approach. Water 2015, 86, 17-24.

19. Mattle, M.J.; Vione, D.; Kohn, T. Conceptual model and experimental framework to determine the contributions of direct and indirect photoreactions to the solar disinfection of MS2, phiX174, and adenovirus. Environ. Sci. Technol. 2015, 49, 334-342. [CrossRef]

20. Binas, V.; Venieri, D.; Kotzias, D.; Kiriakidis, G. Modified $\mathrm{TiO}_{2}$ based photocatalysts for improved air and health quality. J. Materionomics 2017, 3, 3-16. [CrossRef]

21. Lucas, M.; Moulin, L.; Wurtzer, S. Interaction of human enteric viruses with microbial compounds: Implication for virus persistence and disinfection treatments. Environ. Sci. Technol. 2017, 51, 13633-13640.

22. Rtimi, S.; Kiwi, J.; Pulgarin, C.; Karimi, A.; Sanjinés, R. First evidence for the $\mathrm{Ti}_{1-\mathrm{x}} \mathrm{Nb}_{\mathrm{x}}-\mathrm{Ag}$ film hybrid catalytic self-sterilization induced either by visible light or by thermal treatment: Synthesis, mechanism and surface properties. Appl. Mater. Interfaces 2018, 10, 12021-12030. [CrossRef] [PubMed]

23. Rtimi, S.; Dionysiou, D.D.; Pillai, S.C. Advances in bacterial inactivation by $\mathrm{Ag}, \mathrm{Cu}, \mathrm{Cu}-\mathrm{Ag}$ coated surfaces and medical devices. Appl. Catal. B 2019, 240, 291-318. [CrossRef] 
24. Reza, K.; Kurny, A.S.W.; Gulsham, F. Parameters affecting the photocatalytic degradation of dyes using $\mathrm{TiO}_{2}$ : A review. Appl Water Sci. 2017, 7, 1569-1578. [CrossRef]

25. Nesic, J.; Rtimi, S.; Laub, D.; Pulgarin, C.; Roglic, G.M.; Kiwi, J. New evidence for $\mathrm{TiO}_{2}$ uniform surfaces leading to complete bacterial reduction in the dark: Critical issues. Colloids Surf. B Biointerfaces 2014, 123, 593-599. [CrossRef]

26. Rtimi, S.; Nesic, J.; Pulgarin, C.; Sanjines, R.; Bensimon, M.; Kiwi, J. Effect of surface pretreatment of TiO ${ }_{2}$ films on interfacial processes leading to bacterial inactivation in the dark and under light irradiation. Interface Focus 2015, 5, 20140046. [CrossRef]

27. Habibi-Yanggieh, A.; Asadzadeh, S.; Feizpoor, S.; Rouhi, A. Review on heterogeneous photocatalytic disinfection of waterborne, airborne, and foodborne viruses: Can we win against pathogenic viruses? J. Colloid Interface Sci. 2020, 580, 503-514. [CrossRef]

28. Carratala, A.; Calado, A.D.; Mattle, M.J.; Meierhofer, R.; Luzi, S.; Kohn, T. Solar disinfection of viruses in polyethylene terephthalate bottles. Appl. Environ. Microbiol. 2016, 82, 279-288. [CrossRef]

29. Banerjee, S.; Pillai, S.C.; Falaras, P.; O'Shea, K.E.; Byrne, J.A.; Dionysiou, D.D. New insights into the mechanism of visible light photocatalysis. J. Phys. Chem. Lett. 2014, 5, 2543-2554. [CrossRef]

30. Yu, J.; Wang, T.; Rtimi, S. Magnetically separable $\mathrm{TiO}_{2} / \mathrm{FeOx} / \mathrm{POM}$ accelerating the photocatalytic removal of the emerging endocrine disruptor: 2,4-dichlorophenol. Appl. Catal. B Environ. 2019, 254, 66-75. [CrossRef]

31. Rtimi, S.; Konstantinidis, S.; Britun, N.V.; Nadtochenko, V.; Kmehl, I.; Kiwi, J. New evidence for ag-sputtered materials leading to bacterial inactivation by surface-contact without the release of Ag-ions: End of a long controversy? ACS Appl. Mater. Interfaces 2020, 12, 4998-5007. [CrossRef]

32. Sunada, K.; Watanabe, T.; Hashimoto, K. Bactericidal activity of copper deposited $\mathrm{TiO}_{2}$ thin film under weak UV light illumination. Environ. Sci. Technol. 2003, 37, 4785-4789. [CrossRef] [PubMed]

33. Rtimi, S.; Pulgarin, C.; Kiwi, J. Recent developments in accelerated antibacterial inactivation on 2D Cu-titania surfaces under indoor visible light. Coatings 2017, 7, 20. [CrossRef]

34. Rtimi, S.; Kiwi, J. Recent advances on sputtered films with $\mathrm{Cu}$ in ppm concentrations showing drastic acceleration in bacterial inactivation. Catal. Today 2020, 340, 347-362. [CrossRef]

35. Venieri, D.; Fraggedaki, A.; Kostadima, M.; Chatzisymeon, E.; Binas, V.; Zachopoulos, A.; Kiriakidis, G.; Mantzavinos, D. Solar light and metal-doped $\mathrm{TiO}_{2}$ to eliminate water-transmitted bacterial pathogens: Photocatalyst characterization and disinfection performance. Appl. Catal. B Environ. 2014, 154, 93-101. [CrossRef]

36. Kumar, P. Fundamentals and Techniques of Biophysics and Molecular Biology; Pathfinder Pub: New Delhi, India, 2018.

37. Salin, N.M.D.; Hashim, U.; Nafarizal, N.; Sopon, C.H.; Zahdan, Z. Absorbance analyisis of E. coli bacterial suspension in PDMS-glass base microfluidic. Adv. Mater. Res. 2016, 1133, 65-69.

38. Rtimi, S.; Pulgarin, C.; Sanjines, R.; Nadtochenko, V.; Lavanchy, J.-C.; Kiwi, J. Preparation and mechanism of Cu-decorated $\mathrm{TiO}_{2}-\mathrm{ZrO}_{2}$ films showing accelerated bacterial inactivation. ACS Appl. Mater. Interfaces 2015, 7, 12832-12839. [CrossRef]

39. Zheng, X.; Shen, Z.-P.; Cheng, C.; Shi, L.; Cheng, R.; Yuan, D.-H. Photocatalytic disinfection performance in virus and virus/bacteria system by $\mathrm{Cu}-\mathrm{TiO}_{2}$ nanofibers under visible light. Environ. Pollut. 2018, 237, 452-459. [CrossRef]

40. Lu, P.; Wang, H.; Li, X.; Rui, M.; Zeng, H. Localized surface plasmon resonance of Cu nanoparticles by laser ablation in liquid media. RSC Adv. 2015, 5, 79738-79745. [CrossRef]

41. Wang, X.; Swihart, M.T. Controlling the size, shape, phase, band gap, and localized surface plasmon resonance of $\mathrm{Cu}_{2}-\mathrm{xS}$ and CuxInyS nanocrystals. Chem. Mater. 2015, 27, 1786-1791. [CrossRef]

42. Zheng, P.; Tang, H.; Liu, B.; Kasani, S.; Huang, L.; Wu, N. Origin of strong and narrow localized surface plasmon resonance of copper nano-cubes. Nano Res. 2019, 12, 63-68. [CrossRef]

43. Radzig, M.; Koksharova, O.; Khmel, I.; Ivanov, V.; Yorov, K.; Kiwi, J.; Rtimi, S.; Tastekova, E.; Aybush, A.; Nadtochenko, $\mathrm{V}$. Femtosecond spectroscopy of the Au hot-electron injection into $\mathrm{TiO}_{2}$ : Evidence for $\mathrm{Au} / \mathrm{TiO}_{2}$ plasmon photocatalysis by bactericidal Au-ions and related phenomena. Nanomaterials 2019, 9, 217. [CrossRef] [PubMed]

44. Rtimi, S.; Sanjines, R.; Pulgarin, C.; Kiwi, J. Quasi-instantaneous inactivation by uniform Cu-Ag nano-particulate 3D-surfaces in the dark and under light: Mechanism and dynamics. ACS Appl. Mater. Interfaces 2016, 8, 47-55. [CrossRef] [PubMed]

45. Rtimi, S.; Sanjines, R.; Pulgarin, C.; Kiwi, J. Microstructure of Cu-Ag uniform nanoparticulate composite films on polyurethane 3D-surfaces: Surface properties. ACS Appl. Mater. Interfaces 2016, 8, 56-63. [CrossRef] [PubMed]

46. Rtimi, S.; Pulgarin, C.; Nadtochenko, V.A.; Gostev, F.E.; Shelaev, I.V.; Kiwi, J. FeOx-TiO 2 Film Microstructures Inducing Femtosecond transients with different properties under visible light: Biological implications. Nat. Rep. 2016, 6, 30113-30123.

47. Chang, J.; Chong, K.; Lam, L.; Wong, J.; Kline, K. Biofilm-associated infection by enterococci. Nat. Rev. Microbiol. 2019, 17, 82-94. [CrossRef] [PubMed]

48. Krump, N.; You, J. Molecular mechanism of viral oncogenesis in humans. Nat. Rev. Microbiol. 2018, 16, 684-698. [CrossRef] [PubMed]

49. Keane, D.A.; McGuigan, K.G.; Ibáñez, P.F.; Polo-López, M.I.; Byrne, A.J.; Dunlop, P.S.M.; O’Shea, K.; Dionysiou, D.D.; Pillai, S.C. Solar photocatalysis for water disinfection: Materials and reactor design. Catal. Sci. Technol. 2014, 4, 1211-1226. [CrossRef]

50. Rtimi, S.; Nadtochenko, V.; Kmehl, I.; Bensimon, M.; Kiwi, J. First unambiguous evidence for distinct ionic and surface-contact effects during photocatalytic bacterial inactivation on $\mathrm{Cu}-\mathrm{Ag}$ films: Kinetics, mechanism and energetics. Mater. Today Chem. 2017, 6, 62-74. [CrossRef]

51. Rtimi, S.; Nadtochenko, V.; Khmel, I.; Kiwi, J. Evidence for differentiated ionic and surface cell effects driving bacterial inactivation by way of genetically modified bacteria. Chem. Commun. 2017, 53, 9093-9096. [CrossRef] 
52. Wang, L.; Hu, C.; Shao, L. The antimicrobial activity of nanoparticles: Present situation and prospects for the future. Int. J. Nanomed. 2017, 12, 1227-1249. [CrossRef]

53. Dakal, T.C.; Kumar, A.; Majumdar, R.S.; Yadav, V. Mechanistic basis of antimicrobial actions of silver nanoparticles. Front. Microbiol. 2016, 7, 1831. [CrossRef] [PubMed]

54. Rtimi, S.; Lavanchy, J.-C.; Kiwi, J. A new perspective for $\mathrm{TiO}_{2}-\mathrm{FeOx}$ in Indole degradation. J. Catal. 2016, 342, 184-192. [CrossRef]

55. Leytner, S.; Hupp, J. Evaluation of the energetics of electron trap states in $\mathrm{TiO}_{2}$ aqueous solution interface via time resolved spectroscopy. Chem. Phys. Lett. 2000, 330, 231-236. [CrossRef]

56. Pendelburry, S.R.; Wang, X.; Le Formal, F.; Cornuz, M.; Kafikat, A.; Tilley, S.; Gratzel, M.; Durrant, J. Ultrafast charge carrier recombination and trapping in hematite photoanodes under applied bias. J. Am. Chem. Soc. 2014, 136, 9854-9859. [CrossRef]

57. Rtimi, S.; Sanjines, R.; Kiwi, J.; Pulgarin, C.; Bensimon, M.; Khmel, I.; Nadtochenko, V. Innovative photocatalyst (FeOx-TiO 2 ): Transients induced by femtosecond laser pulse leading to bacterial inactivation under visible light. RSC Adv. 2015, 5, 101751101759. [CrossRef]

58. Rtimi, S.; Kiwi, J. Mechanisms of the Antibacterial Effects of $\mathrm{TiO}_{2}-\mathrm{FeOx}$ under Solar or Visible Light: Schottky Barriers versus Surface Plasmon Resonance. Coatings 2018, 8, 391-396.

59. Eskandari, P.; Farhadian, M.; Nazar, H.; Jeon, B. Adsorption and Photodegradation Efficiency of $\mathrm{TiO}_{2} / \mathrm{Fe}_{2} \mathrm{O}_{3} / \mathrm{PAC}$ and $\mathrm{TiO}_{2} / \mathrm{Fe}_{2} \mathrm{O}_{3} /$ Zeolite Nano-photocatalysts for the Removal of Cyanide. Environ. Sci. Technol. 2019, 58, $2099-2112$.

60. Yang, Y.; Zhang, Q.; Deng, Y.; Zhu, C.; Wang, D.; Li, Z. Synthesis of Nano $\mathrm{TiO}_{2}-\mathrm{Fe}_{2} \mathrm{O}_{3}$, Photocatalyst and photocatalytic degradation properties on oxytetracycline hydrochloride. In Proceedings of the 7th International Conference on Manufacturing Science and Engineering (ICMSE 2017), Zhuhai, China, 11-12 March 2017. [CrossRef]

61. Mishra, M.; Shun, D. Alfa-Fe $\mathrm{O}_{3}$ as photochemical material, review. Appl. Catal. A Gen. 2015, 498, 126-141. [CrossRef]

62. Braymer, J.J.; Stümpfig, M.; Thelen, S.; Mühlenhoff, U.; Lill, R. Depletion of thiol reducing capacity impairs cytosolic but not mitochondrial iron-sulfur protein assembly machineries Joseph. BBA Mol. Cell. Res. 2018, 1866, $240-251$.

63. Kathryn, D.; Held, F. Craig Sylvester, Karen, L. Hopcia and John, E.; Biaglow, Role of Fenton Chemistry in Thiol-Induced Toxicity and Apoptosis. Radiat. Res. 1996, 545, 542-553.

64. Mangayayam, M.; Kiwi, J.; Pulgarin, C.; Zivkovic, I.; Ronnow, H.; Magrez, A.; Rtimi, S. FeOx magnetization enhancing several orders of magnitude of E. coli inactivation by Ag-TiO 2 -nanotubes. Appl. Catal. B Environ. 2017, 201, 438-445. [CrossRef]

65. McEvoy, J.G.; Zhang, Z. Antimicrobial and photocatalytic disinfection mechanisms in silver-modified photocatalysts under dark and light conditions. J. Photochem. Photobiol. C Photochem. Rev. 2014, 19, 62-75. [CrossRef]

66. Kiwi, J.; Rtimi, S. Insight into the Interaction of Magnetic Photocatalysts with the Incoming Light Accelerating Bacterial Inactivation and Environmental Cleaning. Appl. Catal. B Environ. 2021, 281, 119420-119437. [CrossRef]

67. Kamat, P.V. Boosting the efficiency of Quantum Dot Sensitized Solar Cells through Modulation of Interfacial Charge Transfer. Acc. Chem. Res. 2012, 45, 1906-1915. [CrossRef] [PubMed]

68. Ouyang, K.; Dai, K.; Walker, S.L.; Huang, Q.; Yin, X.; Cai, P. Efficient photocatalytic disinfection of Escherichia coli O157: H7 using $\mathrm{C} 70-\mathrm{TiO}_{2}$ hybrid under visible light irradiation. Sci. Rep. 2016, 6, 25702. [CrossRef] [PubMed]

69. Liu, B.; Xue, Y.; Zhang, J.; Han, B.; Zhang, J.; Suo, X.; Mu, L.; Shi, H. Visible-light- driven $\mathrm{TiO}_{2} / \mathrm{Ag}_{3} \mathrm{PO}_{4}$ heterostructures with enhanced antifungal activity against agricultural pathogenic fungi Fusarium graminearum and mechanism insight. Environ. Sci. Nano 2017, 4, 255-265. [CrossRef]

70. Akhavan, O.; Ghaderi, E. Photocatalytic reduction of graphene oxide nanosheets on $\mathrm{TiO}_{2}$ thin film for photoinactivation of bacteria in solar light irradiation. J. Phys. Chem. C 2009, 113, 20214-20220. [CrossRef]

71. Koli, V.B.; Dhodamani, A.G.; Raut, A.V.; Thorat, N.D.; Pawar, S.H.; Delekar, S.D. Visible light photo-induced antibacterial activity of $\mathrm{TiO}_{2}-\mathrm{MWCNTs}$ nanocomposites with varying the contents of MWCNTs. J. Photochem. Photobiol. A Chem. 2016, 328, 50-58. [CrossRef]

72. Fernández-Ibáñez, P.; Polo-López, M.; Malato, S.; Wadhwa, S.; Hamilton, J.; Dunlop, P.; D’sa, R.; Magee, E.; O'shea, K.; Dionysiou, D. Solar photocatalytic disinfection of water using titanium dioxide graphene composites. Chem. Eng. J. 2014, $261,36-44$. [CrossRef]

73. Wang, X.; Li, C. Interfacial charge transfer in semiconductor-molecular photocatalyst systems for proton reduction. J. Photochem. Photobiol. C. Photochem. Rev. 2017, 33, 165-179. [CrossRef]

74. Magdalane, C.M.; Kayiyarasu, K.; Vijaya, J.J.; Siddhardha, B.; Jeyaraj, B. Facile synthesis of heterostructured cerium oxide/yttrium oxide nanocomposite in UV light induced photocatalytic degradation and catalytic reduction: Synergistic effect of antimicrobial studies. J. Photochem. Photobiol. B Biol. 2017, 173, 23-34. [CrossRef] [PubMed]

75. Amanulla, A.M.; Jasmine, S.K.; Shahina, J.; Sundaram, R.; Magdalane, C.M.; Kayiyarasu, K.; Letsolathebe, D.; Mohamed, S.B.; Kennedy, J.; Maaza, M. Antibacterial, magnetic, optical and humidity sensor studies of $\beta-\mathrm{CoMoO}_{4}-\mathrm{Co}_{3} \mathrm{O}_{4}$ nanocomposites and its synthesis and characterization. J. Photochem. Photobiol. B Biol. 2018, 183, 233-241. [CrossRef] [PubMed]

76. Saravanakkumar, D.; Sivaranjani, S.; Kaviyarasu, K.; Ayeshamariam, A.; Ravikumar, B.; Pandiarajan, S.; Veeralakshmi, C.; Jayachandran, M.; Maaza, M. Synthesis and characterization of $\mathrm{ZnO}-\mathrm{CuO}$ nanocomposites powder by modified perfume spray pyrolysis method and its antimicrobial investigation. J. Semicond. 2018, 38, 033001. [CrossRef]

77. Kasinathan, K.; Kennedy, J.; Elavaperumal, M.; Henini, M.; Malik, M. Photodegradation of organic pollutants RhB dye using UV simulated sunlight on ceria based $\mathrm{TiO}_{2}$ nanomaterials for antibacterial applications. Sci. Rep. Nat. 2016, 6, 38064. [CrossRef] [PubMed] 
78. Magdalane, C.M.; Kayiyarasu, K.; Vijaya, J.J.; Siddardha, B.; Jevarai, B. Photocatalytic activity of binary metal oxide nanocomposites of $\mathrm{CeO}_{2} / \mathrm{CdO}$ nanospheres: Investigation of optical and antimicrobial activity. J. Photochem. Photobiol. B Biol. 2016, 163, 77-86. [CrossRef]

79. Rtimi, S.; Baghriche, O.; Pulgarin, C.; Sanjines, R.; Kiwi, J. Innovative $\mathrm{TiO}_{2} / \mathrm{Cu}$ surfaces inactivating bacteria $<5$ min under low intensity visible/actinic light $\mathrm{TiO}_{2} / \mathrm{Cu}$ surfaces. ACS Appl. Mater. Interfaces 2012, 4, 5234-5240.

80. Rtimi, S.; Ballo, M.; Pulgarin, C.; Entenza, J.; Bizzini, A.; Kiwi, J. Duality in the Escherichia coli and Methicillin Resistant Staphylococcus aureus reduction mechanism under actinic light on innovative co-sputtered surfaces. Appl. Catal. A Gen. 2015, 498, 4185-4191. [CrossRef]

81. Ballo, M.; Rtimi, S.; Pulgarin, C.; Hopf, N.; Berthet, A.; Kiwi, J.; Moreillon, P.; Entenza, J.; Bizzini, A. In Vitro and In Vivo Effectiveness of an Innovative Silver-Copper Nanoparticle Coating of Catheters to Prevent Methicillin-Resistant Staphylococcus aureus Infection. Antimicrob. Agents Chemother. 2016, 60, 5349-5356. [CrossRef]

82. Ballo, M.; Rtimi, S.; Mancini, S.; Kiwi, J.; Pulgarin, C.; Entenza, J.; Bizzini, A. Bactericidal activity and mechanism of action of copper sputtered flexible surfaces against multidrug resistant pathogens. Appl. Microbiol. Biotechnol. 2016, 100, 5945-5953. [CrossRef]

83. Ballo, M.K.S.; Rtimi, S.; Kiwi, J.; Pulgarin, C.; Entenza, J.M.; Bizzini, A. Fungicidal Activity of Copper-Sputtered Flexible Surfaces Under Dark and Actinic Light Against Azole-resistant Candida albicans and Candida glabrata. J. Photochem. Photobiol. B Biol. 2017, 174, 229-234. [CrossRef]

84. Long, L.; Cao, D.; Fei, J.; Wang, J.; Zhou, Y.; Jiang, Z.; Jiao, Z.; Shu, H. Effect of surface intrinsic defects on the structural stability and electronic properties of the all-inorganic halide perovskite CsPbI3(0 01$)$ film. Chem. Phys. Lett. 2019, 734, 136719. [CrossRef]

85. Thoulouze, M.I.; Alcover, A. Can virus form biofilms? Trends Microbiol. 2011, 19, 257-262. [CrossRef] [PubMed]

86. Gupta, R.; Modak, J. A Critical review, Bacteria Lysis via Photocatalysis. ChemCatChem 2020, 12, 2148-2170. [CrossRef]

87. Roy, R.; Tiwari, M.; Donelli, F.; Tiwari, V. Strategies of combating bacterial biofilms: A focus on antibiofilm agents and their mechanism of action. Virulence 2018, 9, 522-554. [CrossRef] [PubMed] 